\title{
Defining and targeting health disparities in chronic obstructive pulmonary disease
}

\author{
This article was published in the following Dove Press journal: \\ International Journal of COPD \\ 4 October 2016 \\ Number of times this article has been viewed
}

\section{Roy A Pleasants ${ }^{1-3}$ \\ Isaretta L Riley'-3 \\ David M Mannino4}

'Duke Asthma, Allergy, and Airways Center, ${ }^{2}$ Division of Pulmonary, Allergy, and Critical Care Medicine, Duke University School of Medicine, ${ }^{3}$ Durham VA Medical Center, Durham, NC, ${ }^{4}$ Division of Pulmonary, Critical Care, and Sleep Medicine, Pulmonary Epidemiology Research Laboratory, University of Kentucky, Lexington, KY, USA
Correspondence: Roy A Pleasants Duke Asthma, Allergy, and Airways Center, Duke University School of Medicine, 182I Hillandale Road, Suite 25A, Durham, NC 27705, USA Email roy.pleasants@duke.edu

\begin{abstract}
The global burden of chronic obstructive pulmonary disease (COPD) continues to grow in part due to better outcomes in other major diseases and in part because a substantial portion of the worldwide population continues to be exposed to inhalant toxins. However, a disproportionate burden of COPD occurs in people of low socioeconomic status (SES) due to differences in health behaviors, sociopolitical factors, and social and structural environmental exposures. Tobacco use, occupations with exposure to inhalant toxins, and indoor biomass fuel (BF) exposure are more common in low SES populations. Not only does SES affect the risk of developing COPD and etiologies, it is also associated with worsened COPD health outcomes. Effective interventions in these people are needed to decrease these disparities. Efforts that may help lessen these health inequities in low SES include 1) better surveillance targeting diagnosed and undiagnosed COPD in disadvantaged people, 2) educating the public and those involved in health care provision about the disease, 3 ) improving access to cost-effective and affordable health care, and 4) markedly increasing the efforts to prevent disease through smoking cessation, minimizing use and exposure to BF, and decreasing occupational exposures. COPD is considered to be one the most preventable major causes of death from a chronic disease in the world; therefore, effective interventions could have a major impact on reducing the global burden of the disease, especially in socioeconomically disadvantaged populations.
\end{abstract}

Keywords: health disparities, COPD, interventions, prevention, management, international, socioeconomic status

\section{Introduction}

Health disparities are a major contributor in chronic obstructive pulmonary disease (COPD) around the world..$^{1,2}$ COPD is not unique, as health disparities are found with other chronic diseases and throughout the continuum of care. However, the influence of health disparities and socioeconomic status (SES) on the etiology and outcomes of major noncommunicable chronic diseases is more evident with COPD. Environmental risk factors for developing COPD are more common in low SES people, which include tobacco smoking, environmental tobacco smoke (ETS), indoor and outdoor air pollution, and biomass fuel (BF) exposure. ${ }^{1}$ Furthermore, genetic tendencies for asthma ${ }^{3}$ and nicotine addiction ${ }^{4}$ may contribute to disparities in COPD since some race/ethnic/ tribal groups are overrepresented in low SES stratum in different countries. According to the World Health Organization (WHO), $>90 \%$ of COPD deaths occur in lowincome and middle-income countries (LMICs). ${ }^{5}$ In an effort to reduce the magnitude of COPD in populations that bear a disproportionate burden of disease, initiatives by national and international organizations are presently targeting disparities in respiratory diseases. Continuity in disease prevention and delivery of health care as well as access to appropriate medications for COPD needs to be provided to all segments of 
the population, particularly the disadvantaged. This article provides perspective on the health disparities related to SES in COPD and strategies that may help in efforts to provide quality health care in this population.

\section{Methods}

We conducted systematic searches of the literature in English or articles with English abstracts using bibliographic databases of PubMed/Medline (National Library of Medicine and National Institutes of Health), Embase, and the Cochrane database. We used the keywords "COPD" or "emphysema" or "chronic bronchitis", "socioeconomic status", "poverty", "health disparities", "prevalence", and "outcomes".

\section{Definitions of health disparities and SES}

For all chronic diseases, multiple socioeconomic factors contribute to health disparities including income, education, residential segregation, genetic susceptibility, stress, access to health care, social and physical environment, and employment. Unequal access to quality health care is the foundation of health disparities. However, in general, health disparities are not only a function of whether an individual can afford to buy goods and services that aid good health but also include health behaviors related to lifestyle and the environment. Unhealthy behaviors such as tobacco smoking often provide pleasure and relaxation that help regulate mood, ${ }^{6}$ particularly in low SES people who have significant stressors in life.

Disparities exist when differences in health outcomes or health determinants are observed between populations. A number of organizations have defined health-related disparities including the $\mathrm{WHO},{ }^{7}$ the United States (US) Office of Disease Prevention and Health Promotion, ${ }^{6}$ and international pulmonary organizations such as the American Thoracic Society (ATS), and European Respiratory Society (ERS). ${ }^{8}$ The WHO defines health disparities as:

\footnotetext{
Inequalities that exist when members of certain population groups do not benefit from the same health status as other groups. Further, these disparities occur in the provision of healthcare and access to healthcare across different racial, ethnic and socioeconomic groups. ${ }^{7}$
}

In Healthy People 2020, the US Office of Disease Prevention and Health Promotion describes disadvantaged populations as:

Groups of people who have experienced greater obstacles to health based on their racial or ethnic group; religion,
SES, gender, age, occupation, mental health, cognitive, sensory or physical disability or other characteristics linked to discrimination or exclusion. ${ }^{6}$

A joint 2013 ATS/ERS committee published a policy statement broadly defining disparities in respiratory health similar to the Healthy People 2020 definition - specifically "significant differences in respiratory health that are closely linked to racial ancestry, social, economic and/or environmental differences". ${ }^{8}$

SES is a composite assessment of a person's economic and social position in a society based on several factors including income, occupation, home and neighborhood environment, and educational attainment. These factors are correlated, and it is difficult to identify the independent contribution of each factor on the composite assessment of SES. However, many investigators use a single component of SES, for example, educational attainment or annual income, to represent a person's overall economic and social position in their country. In studies evaluating the SES, education is often defined by years of educational attainment (ie, less than high school (secondary school), high school (secondary school graduate), some college/university, or college/ university graduate.

Income is usually defined by individual annual income or cumulative household income. Since the median annual income varies widely between countries, the income-based definition of "low SES" can also vary widely across the globe. The WHO defines extreme poverty as an individual income less than or equal to the equivalent of 2.00 US dollar (USD) per day. ${ }^{9}$ The United Kingdom, like most of the developed world, defines poverty as $60 \%$ of median income in a country. However, in the US, poverty is defined by the US Census Bureau by comparing income to be three times the cost of a minimum food diet in 1963, which is updated annually for inflation and adjusted for family size, composition (ie, number of adults and children in a household), and age of householders. ${ }^{10}$ For example, in 2014, the US poverty level for a family of five persons was $\sim 29,000$ USD annual income, which was $53.7 \%$ of the 54,000 USD median household income.

Other infrequently used measures of SES include geographical area deprivation which categorizes neighborhoods by global positioning system and median income; number of persons living in household; and occupation (eg, manual labor in industry, service industry, office worker, agricultural worker, housewife, professional worker, and machine operator). ${ }^{11}$ 


\section{Health disparities in respiratory diseases}

Health disparities are more commonly seen for respiratory diseases. The lowest socioeconomic groups are up to 14 times more likely to have respiratory disease than the highest group. ${ }^{8}$ An individual's socioeconomic position usually has continuous and numerous health effects that accumulate over a lifetime, and these long-term environmental exposures lead to diseases such as COPD. Disparities related to SES are evident for a number of respiratory diseases including asthma, COPD, lung cancer, and respiratory tract infections such as tuberculosis. ${ }^{8}$ Lung cancer is clearly more likely to occur in people of low SES, even when adjusting for tobacco use. ${ }^{10}$ In some countries, treated tuberculosis is a relatively common cause of COPD in people of low SES living in low-income, multiple person dwellings. ${ }^{1}$

Compared to other common causes of morbidity and death, COPD appears to be more socioeconomically related than others. In a study considering various causes of death, the association was stronger for COPD than cardiac disease. ${ }^{11}$ This is principally true because smoking and environment play leading roles in lung disease development - and people of lower SES tend to have substantially greater exposures to both of these factors. Although asthma affects all ethnic groups, suboptimal outcomes are disproportionately shared by certain minority groups and economically disadvantaged persons. ${ }^{12,13}$ However, low income has a greater influence on COPD prevalence than on asthma prevalence, ${ }^{14}$ this may be because asthma is more genetically driven whereas COPD is more environmentally induced.

According to the WHO, the social determinants of health are mostly responsible for the health inequities seen within and between countries. ${ }^{15}$ The WHO defines social determinants of health as the conditions in which people are born, grow, work, live, age, and the wider set of forces and systems shaping the conditions of daily life. Whitehead described the principal determinants of health disparities arising from multiple sources; Table 1 provides the correlations relative to COPD. ${ }^{16}$

\section{Health disparities in COPD}

As shown in Tables 2-4, there is a strong relationship between COPD and SES. ${ }^{17-58}$ Environmental factors contributing to the development or worsening of COPD include use of tobacco products, occupation, prenatal and childhood exposures, respiratory tract infections, air pollution, and housing conditions including the use of BF, all of which are more likely to be present in low SES people. In developed countries, the major risk factor for COPD is long-term tobacco product use, whereas in less developed countries, the conditions of the home (BF) and work setting (dust, fumes, and vapors) often have a more substantial impact on health than either personal position in society or tobacco exposure. Consistent with this, a multinational study from the 1970s and 1980s showed there was a poor correlation between COPD mortality and cigarette smoking data among 31 countries. ${ }^{59}$ More recently, the Burden of Obstructive Lung Disease (BOLD) study showed a better correlation of COPD prevalence and tobacco use; however, the relationship was not strong in all settings. ${ }^{60}$

\section{SES and respiratory symptoms}

One would expect that if SES is a risk factor for developing COPD, it would also increase the risk of respiratory symptoms. Studies over the last 2 decades have shown that people of low SES exhibit lower lung function and more respiratory symptoms than those in higher SES groups - typically at least a several-fold difference (Table 2). Whether using forced expiratory volume in

Table I Whitehead's principal determinants of health disparities and COPD correlates

\begin{tabular}{ll}
\hline General determinants of health disparities & Corresponding determinants for COPD \\
\hline Natural biologic variation & Genetic susceptibilities \\
Health-damaging behavior of individuals & Smoking tobacco and/or biomass fuel use \\
Transient health advantage for people who adopt new & Educated people making behavioral changes more readily than those with \\
behaviors first & lower levels of education \\
Health-damaging behavior in which the degree of choice & People being born into and remaining in impoverished and low education \\
of lifestyles is severely restricted & settings \\
Exposure to unhealthy living and working conditions & Exposure to environmental (second-hand) smoke and indoor biomass fuels \\
Inadequate access to health care & People in lower socioeconomic status and having less health care access \\
Natural selection leading to the tendency for the sick & People with advanced COPD become disabled due to disease \\
to move down the social hierarchy &
\end{tabular}

Note: Data adapted from Whitehead M. The concepts and principles of equity and health. Health Promotion Int. 1991;6:217-228. ${ }^{16}$

Abbreviation: COPD, chronic obstructive pulmonary disease. 
Table 2 Relationship between socioeconomic status and respiratory measures

\begin{tabular}{|c|c|c|c|c|}
\hline References & $\begin{array}{l}\text { Population (description } \\
\text { and } \mathbf{N} \text { ) }\end{array}$ & $\begin{array}{l}\text { Socioeconomic status } \\
\text { measure(s) }\end{array}$ & Outcome measure(s) & Main findings \\
\hline $\begin{array}{l}\text { Trinder } \\
\text { et al }{ }^{17}\end{array}$ & $\begin{array}{l}\text { General practices in UK } \\
(\mathrm{N}=4,237)\end{array}$ & $\begin{array}{l}\text { Occupation of } \\
\text { householder }\end{array}$ & Respiratory symptoms & $\begin{array}{l}\text { Severity of respiratory symptoms worse } \\
\text { in people with manual occupation in the } \\
\text { presence of tobacco use }\end{array}$ \\
\hline $\begin{array}{l}\text { Shohami } \\
\text { et } \text { al }^{18}\end{array}$ & $\begin{array}{l}\text { Adults in UK attending general } \\
\text { medical practices }(\mathrm{N}=22,675)\end{array}$ & $\begin{array}{l}\text { Occupation, education } \\
\text { level, and area deprivation }\end{array}$ & Lung function impairment & $\begin{array}{l}\text { Occupation, educational level, and living } \\
\text { in area of deprivation associated with } \\
\text { worse lung function }\end{array}$ \\
\hline $\begin{array}{l}\text { Welle } \\
\text { et al }{ }^{19}\end{array}$ & $\begin{array}{l}\text { Norwegian general population } \\
\text { survey }(\mathrm{N}=1,275)\end{array}$ & Educational level & DLCO & $\begin{array}{l}\text { DLCO related to education in men, not } \\
\text { women }\end{array}$ \\
\hline $\begin{array}{l}\text { Schikowski } \\
\text { et al }{ }^{20}\end{array}$ & Germany ( $N=I, 25 I$, women only) & $\begin{array}{l}\text { Education level, } \\
\text { occupation, and residence }\end{array}$ & $\begin{array}{l}\text { Lung function, } \\
\text { respiratory symptoms, } \\
\text { and air particulate matter }\end{array}$ & $\begin{array}{l}\text { Low education more likely to suffer } \\
\text { from low } F E V_{\text {, and }} \text { were occupationally } \\
\text { exposed to particulate matter }>10 \mathrm{ppm}\end{array}$ \\
\hline $\begin{array}{l}\text { Smith } \\
\text { et } \mathrm{a}^{21}\end{array}$ & $\begin{array}{l}\text { Chinese population (never } \\
\text { smokers) in ten regions } \\
(\mathrm{N}=307,000)\end{array}$ & $\begin{array}{l}\text { Household income and } \\
\text { education level }\end{array}$ & Prevalence of $\mathrm{AO}$ & $\begin{array}{l}\text { AO associated with lower education } \\
\text { and income }\end{array}$ \\
\hline $\begin{array}{l}\text { Kurmi } \\
\text { et } \mathrm{al}^{22}\end{array}$ & $\begin{array}{l}\text { Cross-section of adults in ten } \\
\text { diverse populations across China } \\
(\mathrm{N}=500,000 \text { adults) }\end{array}$ & Household annual income & $\begin{array}{l}\text { Prevalence of } A O \text { and } \\
\text { respiratory symptoms }\end{array}$ & AO inversely related to annual income \\
\hline Liu et $\mathrm{a}^{23}$ & $\begin{array}{l}\text { Cross-sectional survey in one } \\
\text { US state ( } N=4,300 \text { adults })\end{array}$ & Education level & $\begin{array}{l}\text { Prevalence of respiratory } \\
\text { symptoms }\end{array}$ & $\begin{array}{l}\text { Low educational level associated } \\
\text { with higher frequency of respiratory } \\
\text { symptoms, including frequent } \\
\text { productive cough, dyspnea, and SOB } \\
\text { affects ADLs }\end{array}$ \\
\hline
\end{tabular}

Abbreviations: ADLs, activities of daily life; $A O$, airflow obstruction; $D L C O$, diffusion capacity of the lung for carbon monoxide; $F E V_{1}$, forced expiratory volume in I second; Ppm, parts per million; SOB, shortness of breath.

1 second $\left(\mathrm{FEV}_{1}\right)$, the presence of airflow obstruction (AO), or respiratory symptoms, all the studies show more impairment in people with low SES and whether it is based on income, education, or occupation.

\section{SES and COPD prevalence}

Table 3 shows studies of the relationship between SES and COPD prevalence, often showing $>1.5$ to three-fold greater in disadvantaged people; this holds true whether income or educational levels are used to define SES. The prevalence of emphysema, because it is more common in smokers than those exposed to BF, may exhibit a different relationship to SES depending on the country. ${ }^{61}$ The BOLD and PLATINO studies have been the most extensive studies of COPD internationally - both support the relationship between poverty and higher COPD prevalence. ${ }^{60,62}$

In most countries, people of low SES account for the majority of all COPD patients. In the US, although low SES people constitute the minority of the overall population $(<20 \%)$, they account for nearly two-thirds of all patients with COPD ${ }^{63,64}$ or AO. ${ }^{22}$ Similarly, in a study of the Chinese population, people with low educational level accounted for $43 \%$ of the survey population in rural areas but $81 \%$ of those were with COPD. ${ }^{65}$ Finish $^{33}$ and Korean ${ }^{40}$ studies reported that two-thirds of subjects with COPD were in the lowest SES group based on education.

\section{Risk factors for COPD in the lower SES population Tobacco use}

Long-term tobacco use is the most common cause of COPD in developed countries - this is most evident in people with low SES due to relatively high rates of tobacco use. In the US, where overall current use of tobacco is $<20 \%$ of adults, rates of current smoking are three- to fivefold higher in those with less than a high school education compared with college graduates. ${ }^{66}$ One of the authors of this article undertook a quality improvement project in four indigent medical clinics and found that current smoking rates were $>70 \%$ among adult patients (R Pleasants, Duke Asthma, Allergy, and Airways Center, Duke University School of Medicine, personal communication, June, 2013). Often, these exposures begin early in life, as children in low SES settings are more likely to be exposed to environmental tobacco smoke from household members and these same people are more likely to eventually smoke tobacco products.

Some epidemiologic studies (for example, Twyman et $\mathrm{al}^{67}$ ) have shown that low education is associated with 
Table 3 Relationship between socioeconomic status and COPD prevalence

\begin{tabular}{|c|c|c|c|c|}
\hline References & $\begin{array}{l}\text { Population, description, } \\
\text { and } \mathbf{N}\end{array}$ & $\begin{array}{l}\text { Socioeconomic } \\
\text { status measure(s) }\end{array}$ & Outcome measure(s) & Main findings \\
\hline Bakke et a ${ }^{24}$ & $\begin{array}{l}\text { Cross-sectional study of general } \\
\text { adult population in Norway } \\
(\mathrm{N}=I, 5 \mathrm{I})\end{array}$ & Occupation & $\begin{array}{l}\text { Asthma and COPD } \\
\text { prevalence }\end{array}$ & $\begin{array}{l}\text { OR of } 3.6 \text { for obstructive lung disease } \\
\text { in people with high degree of airborne } \\
\text { exposure }\end{array}$ \\
\hline Eachus et $\mathrm{al}^{25}$ & $\begin{array}{l}\text { Adults from } 40 \text { general practices } \\
\text { in the UK }(\mathrm{N}=28,080)\end{array}$ & $\begin{array}{l}\text { Deprivation score } \\
\text { based on residence }\end{array}$ & $\begin{array}{l}\text { Disease prevalence } \\
\text { including COPD }\end{array}$ & $\begin{array}{l}\text { Emphysema and chronic bronchitis } \\
\text { relative index of } 2.72 \text { and } 2.27 \text {, } \\
\text { respectively (values higher than most } \\
\text { other conditions) }\end{array}$ \\
\hline Chen et $\mathrm{a}^{26}$ & $\begin{array}{l}\text { National population survey in } \\
\text { Canada }(\mathrm{N}=7,210)\end{array}$ & Income & $\begin{array}{l}\text { COPD disease } \\
\text { prevalence }\end{array}$ & $\begin{array}{l}\text { For low income persons } O R=3.7 \text { for } \\
\text { males and } 2.4 \text { for females }\end{array}$ \\
\hline Marmot et $\mathrm{al}^{27}$ & $\begin{array}{l}\text { Civil servants in London, UK } \\
(\mathrm{N}=10,308)\end{array}$ & $\begin{array}{l}\text { Occupation } \\
\text { (employment grade) }\end{array}$ & $\begin{array}{l}\text { Chronic bronchitis } \\
\text { prevalence }\end{array}$ & $\begin{array}{l}\text { OR for } C B \text { for men } 1.44 \text { and women } \\
I .21\end{array}$ \\
\hline $\begin{array}{l}\text { Montnemery } \\
\text { et } \mathrm{a}^{28}\end{array}$ & Adults in Sweden $(\mathrm{N}=\mid 2,07 \mathrm{I})$ & $\begin{array}{l}\text { Occupation, social } \\
\text { position, and } \\
\text { residence location }\end{array}$ & $\begin{array}{l}\text { Prevalence of } \mathrm{CBE} \text { and } \\
\text { respiratory symptoms }\end{array}$ & $\begin{array}{l}\text { CBE more common in unskilled } \\
\text { and semiskilled workers, low social } \\
\text { position }\end{array}$ \\
\hline Lindberg et al ${ }^{29}$ & Sweden $(\mathrm{N}=1,165)$ & Occupation & $\begin{array}{l}\text { COPD incidence over } \\
10 \text { years in subjects with } \\
\text { respiratory symptoms }\end{array}$ & $\begin{array}{l}\text { Manual workers had an } \mathrm{OR}=1.78 \text { vs } \\
\text { professionals. Low education level had } \\
\text { an } \mathrm{OR}=1.73\end{array}$ \\
\hline $\begin{array}{l}\text { Ellison-Loschmann } \\
\text { et } \mathrm{al}^{30}\end{array}$ & $\begin{array}{l}\text { European Community } \\
\text { respiratory health Survey in } \\
\text { Europe, Australia, New Zealand, } \\
\text { and the US }\end{array}$ & $\begin{array}{l}\text { Educational level and } \\
\text { occupational class }\end{array}$ & $\begin{array}{l}\text { Prevalence and } \\
\text { incidence of chronic } \\
\text { bronchitis }\end{array}$ & $\begin{array}{l}\text { Low educational and occupational } \\
\text { levels (prevalence ratio =1.9 and } 1.8 \text {, } \\
\text { respectively) }\end{array}$ \\
\hline $\begin{array}{l}\text { Halvorsen and } \\
\text { Matrinussen }\end{array}$ & $\begin{array}{l}\text { Norwegian prescription } \\
\text { database of COPD patients } \\
(\mathrm{N}=62,882)\end{array}$ & $\begin{array}{l}\text { Educational level and } \\
\text { level of unemployment } \\
\text { in community }\end{array}$ & COPD prevalence & $\begin{array}{l}\text { Communities with low educational } \\
\text { levels and unemployment associated } \\
\text { with higher risk of COPD }\end{array}$ \\
\hline Karnevisto et a $\left.\right|^{33}$ & $\begin{array}{l}\text { Finland - national population- } \\
\text { wide survey }(\mathrm{N}=6,525)\end{array}$ & $\begin{array}{l}\text { Education and } \\
\text { household income }\end{array}$ & $\begin{array}{l}\text { COPD and asthma } \\
\text { prevalence }\end{array}$ & $\begin{array}{l}\text { Education significant risk factor for } \\
\text { COPD, whereas low household income } \\
\text { was a risk factor for asthma }\end{array}$ \\
\hline Lovasi et $\mathrm{a}^{34}$ & $\begin{array}{l}\text { Multi-ethnic study of arthero- } \\
\text { sclerosis at multiple sites in } \\
\text { the US }(N=3,706)\end{array}$ & $\begin{array}{l}\text { Education, household } \\
\text { income, and wealth } \\
\text { indicators }\end{array}$ & $\begin{array}{l}\text { Degree of emphysema } \\
\text { on computed } \\
\text { tomography scan }\end{array}$ & $\begin{array}{l}\text { Higher percent of emphysema in people } \\
\text { with lower high school education, } \\
\text { annual income, and wealth }\end{array}$ \\
\hline Yin et $a^{35}$ & $\begin{array}{l}\text { People's Republic of China } \\
\text { (3I provinces), }(\mathrm{N}=49,363)\end{array}$ & $\begin{array}{l}\text { Education and } \\
\text { household income }\end{array}$ & $\begin{array}{l}\text { COPD prevalence by } \\
\text { self-report }\end{array}$ & $\begin{array}{l}\text { SES predictive of COPD risk } \\
\text { independent of smoking and rural vs } \\
\text { urban residence }\end{array}$ \\
\hline Herrick et $\mathrm{a}^{36}$ & $\begin{array}{l}\text { Cross-sectional population } \\
\text { study in one US state } \\
(\mathrm{N}=25,986)\end{array}$ & $\begin{array}{l}\text { Annual household } \\
\text { income and highest } \\
\text { level of education }\end{array}$ & COPD prevalence & $\begin{array}{l}\text { COPD prevalence threefold greater } \\
\text { between highest and lowest income } \\
\text { levels as well as between lowest and } \\
\text { highest education levels }\end{array}$ \\
\hline Burney et $\mathrm{al}^{60}$ & $\begin{array}{l}\text { Multicenter ( } \mathrm{n}=22 \text { countries), } \\
\text { international study burden } \\
\text { of obstructive lung disease } \\
(\mathrm{N}=15,355)\end{array}$ & $\begin{array}{l}\text { Poverty as measured } \\
\text { by GNI of countries }\end{array}$ & COPD prevalence & $\begin{array}{l}\text { COPD prevalence fivefold greater } \\
\text { between highest and lowest income } \\
\text { levels as well as between lowest and } \\
\text { highest education levels }\end{array}$ \\
\hline Kainu et a ${ }^{37}$ & $\begin{array}{l}\text { Finnish population }(\mathrm{N}=8,000 \text {, } \\
\text { COPD } N=628)\end{array}$ & Occupation & COPD prevalence & $\begin{array}{l}\text { Prevalence higher in manual than } \\
\text { nonmanual occupations }\end{array}$ \\
\hline Golec et $\mathrm{al}^{38}$ & Polish farmers $(\mathrm{N}=64)$ & Size of farm & COPD prevalence & Lower SES in COPD patients \\
\hline Hagstad et a ${ }^{39}$ & $\begin{array}{l}\text { Swedish never-smokers with } \\
\text { obstructive lung disease } \\
(\mathrm{N}=967)\end{array}$ & $\begin{array}{l}\text { Education level, } \\
\text { occupation }\end{array}$ & $\begin{array}{l}\text { Proportion of } \\
\text { nonsmokers with } \\
\text { COPD who had } \\
\text { occupational exposures }\end{array}$ & $\begin{array}{l}\text { OR of COPD related to } \\
\text { occupation }=0.72 \text { in college graduates } \\
\text { vs those with less than high-school } \\
\text { education }\end{array}$ \\
\hline Lee et a ${ }^{40}$ & $\begin{array}{l}\text { Korean never smokers with } \\
\operatorname{COPD}(N=3,473)\end{array}$ & $\begin{array}{l}\text { Educational level, } \\
\text { occupation }\end{array}$ & COPD prevalence & $\begin{array}{l}\text { Low education level and manual labor } \\
\text { were risk factors for COPD }\end{array}$ \\
\hline Tan et $\mathrm{a}^{41}$ & $\begin{array}{l}\text { Canadian cross-sectional study } \\
\text { in general adult population } \\
(\mathrm{N}=5,176)\end{array}$ & Educational level & $\begin{array}{l}\text { COPD prevalence in } \\
\text { ever and never-smokers }\end{array}$ & $\begin{array}{l}\text { Low education level associated with } \\
\text { higher prevalence in both never and } \\
\text { ever-smokers }\end{array}$ \\
\hline
\end{tabular}

Abbreviations: $\mathrm{CB}$, chronic bronchitis; $\mathrm{CBE}$, chronic bronchitis/emphysema; COPD, chronic obstructive pulmonary disease; GNI, gross national income; OR, odds ratio; SES, socioeconomic status. 
Table 4 Effect of socioeconomic status on respiratory-related outcomes in chronic obstructive pulmonary disease

\begin{tabular}{|c|c|c|c|c|}
\hline References & Population & SES measure & Outcome measure(s) & Main findings \\
\hline Prescott et $\mathrm{a}^{43}$ & $\begin{array}{l}\text { Copenhagen, Denmark } \\
\text { general population } \\
(\mathrm{N}=\mid 4,223)\end{array}$ & $\begin{array}{l}\text { Educational level and } \\
\text { household income }\end{array}$ & Hospitalization for COPD & $\begin{array}{l}\text { Higher rates of hospitalization } \\
\text { related to income and education } \\
\text { levels (independent of smoking } \\
\text { history) }\end{array}$ \\
\hline Van Rossum et al ${ }^{42}$ & $\begin{array}{l}\text { the Netherlands } \\
(\mathrm{N}=\mid 8,00 \mathrm{I})\end{array}$ & Occupation & Mortality & $\begin{array}{l}\text { COPD had highest rate of } \\
\text { increased mortality related to } \\
\text { occupation compared with other } \\
\text { common causes of death }\end{array}$ \\
\hline Steenland et al" & $\begin{array}{l}\text { Adults in } 27 \text { states in the } \\
\text { US, American Cancer } \\
\text { Society population } \\
(\mathrm{N}=1,330,886)\end{array}$ & Occupation & $\begin{array}{l}\text { All cause and cause-specific } \\
\text { mortality }\end{array}$ & $\begin{array}{l}\text { SES gradient most substantial for } \\
\text { all specific causes of death }\end{array}$ \\
\hline Huisman et $\mathrm{al}^{44}$ & $\begin{array}{l}\text { European data from } \\
\text { numerous countries } \\
\text { ( } \mathrm{N}=\mathrm{I}, 000,000 \text { deaths) }\end{array}$ & Education level & $\begin{array}{l}\text { Mortality rate in low- } \\
\text { educational groups expressed } \\
\text { as a proportion of mortality } \\
\text { rate in high-educational groups }\end{array}$ & $\begin{array}{l}\text { Low education groups had highest } \\
\text { mortality including COPD, cancer, } \\
\text { and heart disease }\end{array}$ \\
\hline $\begin{array}{l}\text { Antonelli-Incazi } \\
\text { et a } 4^{45}\end{array}$ & Elderly in Rome, Italy & $\begin{array}{l}\text { Income based upon } \\
\text { census tract estimate for } \\
\text { residence }\end{array}$ & Hospitalization rate of COPD & $\begin{array}{l}\text { Relative risk for females with } \\
\text { COPD } 3.3 \text { and males } 4.3 \text { (higher } \\
\text { than other diseases) }\end{array}$ \\
\hline Blanc et $\mathrm{al}^{46}$ & $\begin{array}{l}\text { US population survey of } \\
\text { COPD patients }(\mathrm{N}=427)\end{array}$ & $\begin{array}{l}\text { Educational level and } \\
\text { annual income }\end{array}$ & Tiotropium use & $\begin{array}{l}\text { Less use of tiotropium with lower } \\
\text { SES }(O R=0.3)\end{array}$ \\
\hline Reilly et a ${ }^{47}$ & $\begin{array}{l}\text { National survey of } 30 \\
\text { provinces in the People's } \\
\text { Republic of China } \\
(\mathrm{N}=169,87 \mathrm{I})\end{array}$ & $\begin{array}{l}\text { Education, residence } \\
\text { (urban vs rural) }\end{array}$ & Mortality & $\begin{array}{l}\text { Relative risk of death } 2.37 \\
\text { and } 2.47 \text { for men and women, } \\
\text { respectively. RR for urban vs } \\
\text { rural residence } 2.14 \text { and } 1.79 \text {, } \\
\text { respectively }\end{array}$ \\
\hline Schane et $\mathrm{al}^{48}$ & $\begin{array}{l}\text { National cross-sectional } \\
\text { US survey }(\mathrm{N}=18,858 \\
\text { total } \mathrm{N}=1,736 \text { COPD } \\
\text { patients) }\end{array}$ & Income and education & $\begin{array}{l}\text { Risk factors for depression in } \\
\text { COPD vs non-COPD }\end{array}$ & $\begin{array}{l}\text { Less than HS education showed } \\
\mathrm{OR}=1.63 \text { for depression }\end{array}$ \\
\hline Wong et $\mathrm{al}^{49}$ & $\begin{array}{l}\text { Data from St Paul's } \\
\text { Hospital in Vancouver, } \\
\text { BC, Canada }\end{array}$ & $\begin{array}{l}\text { Marital status and need for } \\
\text { social work consultation } \\
\text { while in hospital }\end{array}$ & $\begin{array}{l}\text { Hospital LOS and readmission } \\
\text { rate in AECOPD patients }\end{array}$ & $\begin{array}{l}\text { Marital status and need for social } \\
\text { work intervention associated with } \\
\text { prolonged LOS and readmission } \\
\text { for AECOPD }\end{array}$ \\
\hline Lewis et $\mathrm{a}^{10}$ & $\begin{array}{l}\text { National Longitudinal } \\
\text { Mortality Study in the US } \\
(\mathrm{N}=184,924)\end{array}$ & $\begin{array}{l}\text { Marital status, education, } \\
\text { health insurance, poverty } \\
\text { level, and occupation }\end{array}$ & $\begin{array}{l}\text { Mortality in a general adult } \\
\text { population }\end{array}$ & $\begin{array}{l}\text { Education, marital status, and } \\
\text { income predictive of mortality, not } \\
\text { seen with insured vs uninsured }\end{array}$ \\
\hline Arne et $a^{50}$ & $\begin{array}{l}\text { Sweden, survey of } 55 \\
\text { municipalities }(N=I, 475)\end{array}$ & $\begin{array}{l}\text { Education level, } \\
\text { employment status, and } \\
\text { social support }\end{array}$ & $\begin{array}{l}\text { Health status and quality of } \\
\text { life in COPD vs non-COPD } \\
\text { subjects }\end{array}$ & $\begin{array}{l}\text { Lack of social support and low } \\
\text { economic status associated with } \\
\text { poorer health status in COPD }\end{array}$ \\
\hline $\begin{array}{l}\text { Calderón-Larrañaga } \\
\text { et } \mathrm{al}^{51}\end{array}$ & $\begin{array}{l}\text { UK, national cross- } \\
\text { sectional study } \\
(\mathrm{N}=53,676,02 \mathrm{I})\end{array}$ & Deprivation index & Hospitalizations for COPD & $\begin{array}{l}\text { Deprivation and smoking } \\
\text { prevalence were variables with } \\
\text { highest explanatory power, } \\
\text { accounting for } 59.3 \% \text { and } 51.4 \% \\
\text { of the total variance, respectively }\end{array}$ \\
\hline Miravitlles et a ${ }^{52}$ & $\begin{array}{l}\text { Spain, nationwide survey } \\
(\mathrm{N}=4,574)\end{array}$ & $\begin{array}{l}\text { Education level and } \\
\text { occupation }\end{array}$ & HrQOL in COPD patients & $\begin{array}{l}\text { Worse HrQOL in low education } \\
\text { level and in unskilled workers }\end{array}$ \\
\hline Eisner et $\mathrm{al}^{31}$ & $\begin{array}{l}\mathrm{CA} \text {, in the US }(\mathrm{N}=\mathrm{I}, 202) \\
\text { (insured COPD patients) }\end{array}$ & $\begin{array}{l}\text { Education and income } \\
\text { levels }\end{array}$ & $\begin{array}{l}\text { Physical impairment (6-minute } \\
\text { walk), pulmonary function, } \\
\text { and disease severity including } \\
\text { BODE index }\end{array}$ & $\begin{array}{l}\text { Low SES associated with worse } \\
\text { physical impairment, pulmonary, } \\
\text { function, and disease severity in } \\
\text { a COPD population with broad } \\
\text { access to health care }\end{array}$ \\
\hline Omachi et al $^{53}$ & $\begin{array}{l}C A \text {, in the US, population } \\
\text { survey in persons } \\
>55 \text { years }(N=277)\end{array}$ & Health literacy & $\begin{array}{l}\text { COPD-related health status } \\
\text { and COPD-related ED } \\
\text { or hospitalizations using } \\
\text { multifactorial analysis adjusted } \\
\text { for income and educational levels }\end{array}$ & $\begin{array}{l}\text { Poorer health literacy associated } \\
\text { with worse health status, HrQOL, } \\
\text { and ED and hospitalizations for } \\
\text { COPD }\end{array}$ \\
\hline
\end{tabular}


Table 4 (Continued)

\begin{tabular}{|c|c|c|c|c|}
\hline References & Population & SES measure & Outcome measure(s) & Main findings \\
\hline McAllister et $\mathrm{a}^{54}$ & All Scottish residents (UK) & $\begin{array}{l}\text { Scottish Index of Multiple } \\
\text { Deprivation (measure } \\
\text { using multiple domains } \\
\text { such as income, housing, } \\
\text { access, education) }\end{array}$ & $\begin{array}{l}\text { Hospitalization rates in COPD } \\
\text { associated with deprivation } \\
\text { index and winter season }\end{array}$ & $\begin{array}{l}\text { SES and winter act synergistically } \\
\text { on rate of COPD hospitalizations }\end{array}$ \\
\hline Gershon et $\mathrm{al}^{55}$ & ON, Canada & $\begin{array}{l}\text { Average household } \\
\text { income based on } \\
\text { residence }\end{array}$ & Mortality of COPD & $\begin{array}{l}\text { Although overall COPD mortality } \\
\text { decreased between } 1966 \text { and } 2012 \text {, } \\
\text { differences in COPD mortality } \\
\text { between low and high income } \\
\text { widened over the study period }\end{array}$ \\
\hline Lange et $\mathrm{al}^{56}$ & $\begin{array}{l}\text { Copenhagen, Denmark } \\
(\mathrm{N}=6,590) \text { adults with } \\
\text { COPD }\end{array}$ & $\begin{array}{l}\text { Education }<8 \text { years, } \\
8-10 \text { years, }>10 \text { years } \\
\text { with some college or } \\
\text { completed college }\end{array}$ & $\begin{array}{l}\text { AECOPD, hospital admissions, } \\
\text { mortality }\end{array}$ & $\begin{array}{l}\text { Highest risk of AECOPD, } \\
\text { low lung function, and highest } \\
\text { respiratory symptoms }\end{array}$ \\
\hline $\begin{array}{l}\text { Trachtenberg } \\
\text { et } \mathrm{al}^{57}\end{array}$ & $\begin{array}{l}\text { Administrative database } \\
\text { in Winnipeg, Canada } \\
\mathrm{N}=34,74 \mathrm{I} \text { asthma and } \\
\mathrm{COPD})\end{array}$ & $\begin{array}{l}\text { Census-based household } \\
\text { income }\end{array}$ & $\begin{array}{l}\text { Hospitalizations for asthma or } \\
\text { COPD }\end{array}$ & $\begin{array}{l}\text { Lower SES associated with higher } \\
\text { risk of hospitalizations }\end{array}$ \\
\hline Sharma et $\mathrm{al}^{58}$ & $\begin{array}{l}\text { US Medicare beneficiaries } \\
\text { with COPD }\end{array}$ & $\begin{array}{l}\text { Socioeconomic status } \\
\text { based on if Medicaid } \\
\text { eligible (low SES) }\end{array}$ & $\begin{array}{l}\text { Burn injuries related to } \\
\text { oxygen use }\end{array}$ & $\begin{array}{l}\text { Twofold risk of oxygen-related } \\
\text { burn injuries in low SES people }\end{array}$ \\
\hline
\end{tabular}

Abbreviations: AECOPD, acute exacerbation of COPD; COPD, chronic obstructive pulmonary disease; ED, emergency department; HrQOL, health-related quality of life; LOS, length of stay; OR, odds ratio; RR, relative risk; SES, socioeconomic status.

lower odds of quitting tobacco compared with persons of higher educational attainment. Some hypotheses include 1) impoverished people are less likely to seek treatment for tobacco addiction because of significant life stressors, 2) smoking is often socially accepted among their family and peers, 3) they have lower levels of knowledge of benefits of smoking cessation drug therapies, 4) health care providers believe that this population is less interested in quitting smoking, 5) they have higher rates of mental health issues including multisubstance abuse, and 6) genetics. Though these are hypothesized explanations for the disparity in smoking cessation rates in low SES groups, there are no randomized controlled data to support a causal relationship. In addition, many epidemiologic studies often leave out key variables in their analysis. One study found that smoking behaviors including age of initiation, intensity of tobacco use, and smoking cessation capabilities appear to be genetically related. ${ }^{68}$ In the COPD Gene trial, it was found that in a genetic analysis of $>3,000$ COPD patients, the age of onset of tobacco use and smoking cessation behavior were related to nicotinic receptors and hepatic metabolism of nicotine. ${ }^{4}$ Neither study examined the relationship of genetics, smoking, and SES.

However, in less-developed countries with very wide social gradients, the poorest are unable to afford tobacco products, and therefore, long-term tobacco use is less likely to be the leading cause of COPD. In Peru where tobacco use is very low in the adult population (3.3\%), smoking accounts for $<10 \%$ of all COPD cases. COPD was more likely to be due to posttuberculosis infection and indoor $\mathrm{BF}$; the latter accounting for $60 \%$ of the COPD cases. ${ }^{69}$ In some countries such as Uganda, some of the poor grow their own tobacco and therefore have ready access to tobacco.

\section{Occupation}

In the US, it is estimated that $\sim 15 \%$ of COPD cases could be attributed to inhaled particles at work such as production of plastics, textiles and leather, building and construction, military service, food, crops, chemicals, petroleum, and coal mines. ${ }^{70}$ Disadvantaged people tend to be the ones working in these environments. However, occupation-related COPD often does not occur in isolation, as many at-risk people have exposures to harmful particles in the household and outdoor environments. A greater risk of COPD has been reported with combined occupational and smoking exposures. The odds ratios ranged from 4.0 to 6.2 for COPD among occupationally exposed smokers, compared with 1.4-3.2 for occupationally exposed never-smokers. ${ }^{71,72}$ In another study, the difference between occupationally exposed never-smokers and occupationally exposed ever-smokers was reported to be even greater (14-fold). ${ }^{73}$ 
In a National Health and Nutrition Examination Survey study in the US, occupations associated with an increased risk of COPD were freight, stock, material handlers, records processing and distribution clerks, sales, transportationrelated occupations, machine operators, construction trades, and waitresses. ${ }^{74}$ The fraction of COPD attributable to work was estimated as $19.2 \%$ overall and $31.1 \%$ among never smokers. The majority of workers in high-risk occupations had low income and education levels. In a more recent Swiss study of working adults, occupational exposures to biological dusts, mineral dusts, and gases/fumes were associated with two- to fivefold higher incidence of COPD of at least moderate severity; however, SES measures were not reported. ${ }^{75}$

\section{Household and outdoor pollution}

Almost 3 billion of the world's poorest rely upon solid fuels (wood, animal dung, charcoal, crop wastes, and coal) burned in inefficient, polluting stoves for cooking, lighting, and heating - leading to premature deaths from respiratory and cardiovascular diseases and cancer. ${ }^{76}$ It has been suggested that BF is a more common cause of COPD than cigarette smoke globally. ${ }^{77}$ The use of gas stove and solid fuels for cooking, lighting, and heating ${ }^{78,79}$ and air pollution have been linked to increased respiratory symptoms, impaired lung function, ${ }^{80-82}$ and development of COPD. ${ }^{83,84}$ Although the role of air pollution in causing COPD is not clear, high levels of outdoor pollution are an important contributor to an increased risk of acute exacerbations of COPD $^{85}$ and possibly mortality. ${ }^{86}$

Much of the combustible fuel exposure is related to poor housing conditions such as overcrowding and poor ventilation when using BF. In addition to consistently conferring a higher risk of the emergence of COPD, it also increases the risk of acute respiratory infections. ${ }^{87}$ Women appear to be particularly at risk to develop biomass-related COPD, although environmental tobacco smoke may play a role. ${ }^{80}$ Meta-analyses have reported approximately twofold greater odds of developing COPD in people exposed to BF. ${ }^{84,88}$

In a cohort study in the US, use of wood for indoor heating in fireplaces or woodstoves increases the risk of COPD among current smokers, Caucasians, and men. ${ }^{89}$ These effects remained even when controlling for age, smoking, and educational level. Wood smoke may lead to greater risk of developing COPD, ${ }^{90}$ whereas indoor use of coal for heating may be more likely to increase the risk of lung cancer..$^{91}$

Outdoor air pollution is also an important factor that causes lung diseases in people of low SES as they tend to live in poor housing, less desirable areas in close proximity to highways, and pollution-producing manufacturers and are therefore exposed to disproportionate amounts of inhalant toxins. In the US, the estimated proportion of the population living near a major highway was $4.2 \%$ for the poor, $3.7 \%$ for the near-poor, and $3.5 \%$ for the nonpoor categories. ${ }^{92}$ In a longitudinal study of 4,757 women in Germany, it was found that chronic exposure to $\mathrm{PM}_{10}$ and nitric dioxide and living near a major highway led to an increased risk of COPD (1.8-fold). ${ }^{20}$

\section{Intrauterine and childhood exposures}

Exposures, beginning with the fetus continuing throughout childhood, can have an impact on the trajectory of lung function development and ultimately long-term respiratory health. Intrauterine exposure to tobacco as well as secondhand smoke in young people are important risk factors for developing both asthma and COPD, especially in disadvantaged people. ${ }^{93-99}$ In the US, smoking rates in women during the 3 months prior to pregnancy are similar to the general population $(\sim 20 \%)$, decline to $\sim 10 \%$ of women while pregnant, and then increase close to pre-pregnancy rates postpartum. ${ }^{100}$ Women of low SES tend to smoke more during and after pregnancy. In a UK study, women of low SES were three times more likely to smoke during pregnancy than higher SES women. ${ }^{101}$ One study found a positive association between fetal size at 10 weeks gestation and $\mathrm{FEV}_{1}$ in 10-year olds. ${ }^{95}$ Another study found that smoking during pregnancy, particularly in first trimester, is associated with worse respiratory complications in children. ${ }^{102}$

Lung function impairment and respiratory symptoms after birth and through childhood are also associated with asthma occurrence in later years, ${ }^{95-97}$ ultimately increasing the risk of developing COPD later in life. ${ }^{100,103}$ In children, chronic exposure to air pollution is associated with a reduction in agerelated forced vital capacity and lung growth. ${ }^{104}$ However, other studies found that there was no effect or inconclusive evidence for longitudinal changes in lung function. ${ }^{94,105,106}$ A Swedish study of 2,278 children looked at the effect of air quality during the first year of life on lung function at 16 years of age. ${ }^{93}$ Early life exposures to traffic-related air pollution during the first year of life resulted in lower $\mathrm{FEV}_{1}$, especially in males. Biomass smoke is also an independent risk factor for COPD in people exposed in early life ${ }^{84}$ Lastly, impaired lung function in early adulthood is also associated with an increased risk of developing COPD. ${ }^{107}$

It is also known that recurrent childhood respiratory tract infections can lead to the development of lung diseases later in life ${ }^{108-111}$ and that low SES increases the risk of childhood respiratory tract infections. In one study early childhood respiratory infections as well as a history of 
asthma in the family were significant determinants of COPD risk. ${ }^{110}$ A recent 50-year longitudinal study of a cohort of children beginning at 10-15 years of age found that asthma and wheezy bronchitis associated with viral infections led to increased risk of developing COPD, while considering smoking history. ${ }^{111}$

\section{Health care access}

Disparities in health care access persist despite efforts for many years to improve care for underserved patients, ethnic and racial minorities, and the underinsured. Access to health care providers, diagnostic testing, and medications are often more limited in disadvantaged people, although universal health insurance in some countries lessen health disparities. In addition to access being an issue in the low SES people, lower literacy levels also impact their health status and other outcomes. ${ }^{53}$

Shortage of primary care and specialist physicians in some communities is an important factor for the unequal provision of health care quality and access to health care services. ${ }^{112,113}$ In the US, Spain, and many developing countries, relatively few pulmonologists and specialty services such as spirometry and pulmonary rehabilitation are available to disadvantaged people. ${ }^{8}$ In the US, minority patients with asthma are less likely to be referred to specialists than whites. ${ }^{114}$

Access to health care is not the only important factor in health disparities; the Black Report emphasized that despite free health care provision through the National Health Service, health disparities in mortality rates by social class were evident. ${ }^{115}$ A US study showed that in people provided with similar health insurance, those with low SES had worse health outcomes than those at with high SES. ${ }^{31}$ In contrast, a Canadian study found that there was no difference in COPD mortality between people of low and high education - this was felt to be due to universal health coverage and the greater acute health care utilization by low SES people. ${ }^{116}$ Therefore, it is not just a matter of providing health care resources at a low cost to people of low SES, but it must involve other additional strategies to promote healthy behaviors in these patients and other contributors that affect health outcomes.

Disparities also exist in tobacco cessation advice from health care providers. ${ }^{117,118}$ In a US study, compared to Caucasian smokers, African-American and Hispanic smokers were approximately two-thirds less likely to be asked by their doctor about tobacco use and not have used a cessation medication. These differences were unexplained even when factors known to impact these rates were considered. ${ }^{117}$ In another study, low SES people were less likely to receive provider-assisted assistance in stopping smoking than higher SES people. ${ }^{118}$ New quality outcome measures requiring screening for tobacco use by health care providers in the US have decreased this disparity.

Affordability and access to effective COPD medications is a major barrier in many disadvantaged people. In some impoverished countries, the national formularies have very limited choices for the treatment of COPD. One US study showed that low SES people were only one-third as likely to have used their inhaled tiotropium. ${ }^{46}$ An important problem with COPD medication costs is the lack of availability of cheap generics; in part because regulatory agencies, such as the US Food and Drug Administration, have higher expectations for inhaled generic equivalents than for oral generics. ${ }^{119}$

\section{Clinical characteristics of COPD in people of low SES}

Both biomass and tobacco smoke are generated from the combustion of plant materials, which produce complex carbonbased particles and organic compounds such as hydrocarbons and irritant gases. Biomass smoke increases the expression of some matrix metalloproteinases similar to tobacco smoke. ${ }^{120,121}$ Like tobacco smoke, BF leads to chronic inflammation, increased oxidative stress, and respiratory symptoms. ${ }^{122}$ Combined exposures to tobacco smoke and BF have additive effects on the risk of developing lung diseases. ${ }^{90}$

Clinical features tend to differ between tobacco smokers and people exposed to BF. ${ }^{61,123-126}$ In a study of women with severe COPD, comparing wood smoke-related and tobacco smoke-related COPD, there were no significant differences between the two groups in terms of AO, resistance, or hyperinflation. However, bronchial hyper-reactivity was more evident in the former. ${ }^{123}$ In another study, those exposed to BF scored lower on the symptom and activity scores using a quality of life assessment. ${ }^{61}$ This study also showed that women in the biomass group had significantly more air trapping than the tobacco group (radiologist score was 2.6 and 1.5, respectively) and had lower oxygen saturation at rest and during exercise. In another study in Columbia, South American women with chronic bronchitis secondary to long-term wood smoke inhalation, dyspnea, AO, air trapping, and increased airway resistance were common. ${ }^{125}$ Additional research is needed in this area as tobacco smoking becomes less prevalent and other causes of COPD become more common.

Several studies have examined the radiologic and pathologic characteristics of biomass vs tobacco smoke-related COPD. ${ }^{34,61,125-127}$ One study, using 3,706 multiethnic subjects enrolled from six distinct US locations (Multi-Ethnic Study of Atherosclerosis), examined the relationship among SES, emphysema scores, and other measures. ${ }^{34}$ One-half of the 
subjects were current or former smokers, one-third had occupational dust exposure histories, and one-third were born outside the US. Those who did not complete high school had more AO than those with a graduate degree, whereas, unexpectedly, the less well-educated people had a lesser extent of emphysema. However, to what extent biomass exposures contributed to this discrepancy was unclear. In a study of 43 Mexican women, grouped by tobacco smoking or BF exposure, computed tomography (CT) scans showed that the tobacco group had significantly more emphysema than the biomass group (radiologist score was 2.3 vs 0.7 ; emphysema on CT $27 \%$ vs $19 \%$, and a larger size of emphysematous spaces) ${ }^{61}$ In another study of Mexican women with COPD secondary to wood smoke inhalation $(n=12)$ vs smokingrelated COPD $(n=10)$, pathological evidences of anthracosis, chronic bronchitis, centrilobular emphysema, and pulmonary hypertension were present in most patients exposed to wood smoke. ${ }^{125}$ In an autopsy study of 48 Mexican COPD patients, emphysema was less likely to be severe in BF patients than in smokers. ${ }^{127}$ Small airways fibrosis was more evident with $\mathrm{BF}$, whereas increased goblet cell hyperplasia and emphysema were seen in smokers. Emphysema was more evident in the smokers. In terms of survival, a 7-year follow-up study showed that women with biomass-induced COPD have similar survival rates as men with tobacco-related COPD. ${ }^{124}$

\section{Effect of SES on COPD outcomes}

Table 4 lists the studies that show a strong association between low SES and worse outcomes in COPD patients including death, emergency department (ED) visits, hospitalizations, medication use, and health-related quality of life..$^{11,43,44,54-56,60,128}$ There may be sex differences as one study reported that occupation and education were predictors of death in men, whereas only education was significant in women. ${ }^{43}$ In a systematic review, among several common causes of death (COPD, diabetes, heart disease, all cancers, and stroke), the relationship with SES was strongest for COPD-related deaths. ${ }^{55}$ However, with regard to lung cancer (vs all cancers), the association between SES and risk was also quite strong, ${ }^{128}$ therefore how various causes of death are categorized may affect the reported association between mortality and SES. A BOLD study analysis found that smoking is the most important cause of $\mathrm{AO}$, but airflow restriction was more associated with mortality in poor countries. ${ }^{60}$ With regard to COPD mortality, people in lower SES groups comprise between one-half to three-fourths of all deaths where COPD is reported to be the primary cause. ${ }^{10,11,129}$ A recent Canadian study showed that the mortality gradient between low and high SES is slowly widening (Figure 1). ${ }^{55} \mathrm{In}$ countries where current smoking rates continue to decline in higher SES groups such as the US and Canada, although rates

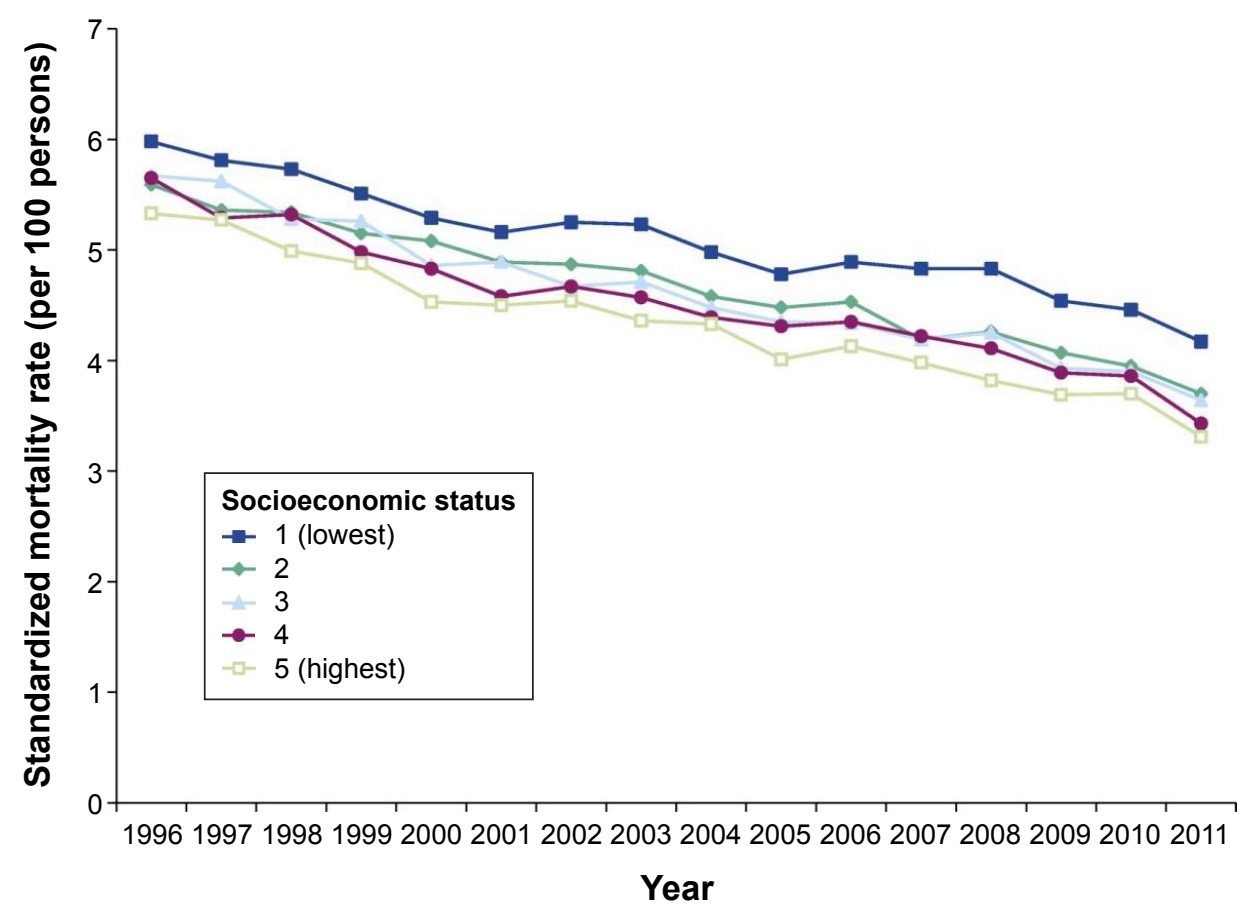

Figure I All-cause mortality rate by socioeconomic status among COPD patients in Canada from 1996/1997 to 201 I/20I2.

Note: Reprinted with permission of the American Thoracic Society. Copyright (C) 2016 American Thoracic Society. Gershon AS, Hwee J, Victor JC, Wilton AS, To T. 2014. Trends in socioeconomic status-related differences in mortality among people with chronic obstructive pulmonary disease. Ann Am Thorac Soc. II:I I95-1202. The Annals of the American Thoracic Society is an official journal of the American Thoracic Society. ${ }^{55}$

Abbreviation: COPD, chronic obstructive pulmonary disease. 
decline more slowly in disadvantaged people, this gradient will likely widen even further. However, the impact of SES on mortality is not seen with all COPD patient types. A UK study found that mortality in alpha- 1 antitrypsin patients was no different as a function of educational status or occupation, ${ }^{130}$ likely because it is a genetically driven cause of COPD.

Other outcome measures that are affected by SES in COPD patients are health-related quality of life, ${ }^{52}$ depression, ${ }^{48}$ medication (tiotropium and albuterol) use, ED visits, hospitalizations, and burn injuries from home supplemental oxygen. ${ }^{58}$ These disparities existed even in people who have ready access to health care. ${ }^{10,31}$ Hospital readmission for acute exacerbation of COPD (AECOPD), now a quality measure in the US hospitals, is also more common in disadvantaged COPD patients. ${ }^{49}$ A UK study, examining the relationship between air pollution and albuterol prescriptions by primary care physicians, found that deprivation was associated with greater prescribing. ${ }^{131}$ Conversely, maintenance therapy use is decreased in low SES people. ${ }^{46}$

\section{Strategies to aid the diagnosis and management of COPD patients with low SES}

There is an old adage in the US supposedly quoted from a famous bank robber named Willie Sutton that evolved into Sutton's law used in clinical medicine. Sutton reputedly replied to a reporter's inquiry why he robbed banks that "because that's where the money is". ${ }^{132}$ Translated into where the greatest opportunities and challenges exist for COPD, it is targeting low SES populations and that is where the money and other resources need to be directed.

In reality, to make substantive changes in COPD risk factors and social determinants of health, health equity strategies must be part of larger, multifaceted efforts that will always depend on societal changes that can be very difficult to achieve. Broadly speaking, there are three important principles that should be included in the strategies to improve COPD health equity: 1) include all stakeholders in the development and implementation of interventions; 2) adapt interventions to address the unique barriers and facilitators of the disparate population; and 3) create implementation strategies targeting all levels of the socioecologic framework - individual, interpersonal, organizational, community, and public policy. Stakeholders can vary from government agencies, health care organizations such as WHO, ATS, ERS, health insurers, health care institutions, research organizations, health care providers, patients, and community groups. The remainder of this section focusses approaches that may be applied by individuals or in local settings.
Some strategies that might be employed include 1) prioritize population screening and case-finding in people of low SES to identify symptomatic people with exposure histories in this high-risk population; 2) undertake educational efforts in people with low SES using culturally sensitive strategies in local communities; optimally beginning at a young age regarding the use of tobacco products, indoor biomass, second-hand smoke, and COPD; 3 ) provide alternatives to the use of indoor biomass cooking; 4) identify cost-effective strategies for health care in this population; and 5) identify existing and potential strategies to save medication costs and optimize adherence.

\section{Organizational strategies}

The WHO, ATS, ERS, Forum of International Respiratory Societies, and European COPD Coalition are among the health care organizations that are responding to the problems surrounding COPD and SES. Some key ATS efforts targeting health disparities include establishing a group called the Lung Corp, ${ }^{133}$ publishing a perspective of respiratory health equality in the US, ${ }^{134}$ and a joint policy statement with ERS on disparities in respiratory health. ${ }^{8}$ The ATS created the Lung Corps to reduce health disparities through the promotion of research, training, disseminating best practices and monitoring, and advocating lung health to the public. In addition, an ATS subcommittee reported that attainment of respiratory health equality necessitates the end of disparities, which would require a multidisciplinary effort targeting environmental exposures, encouraging healthy lifestyles, and optimizing the prevention, screening, diagnosis, and management of lung diseases. ${ }^{136} \mathrm{~A}$ joint ATS/ERS policy statement ${ }^{8}$ describes actions including developing educational programs for health care providers and policy makers to reduce disparities, holding conferences addressing health care disparities, and collaborating with other organizations such as the WHO. ATS/ERS jointly plans to decrease disparities by 1) guiding research agendas, 2) increasing healthcare provider awareness of disparities, 3) advocating for appropriate policies, and 4) tracking progress with disparities. Nearly 2 decades ago, ATS developed the Methods in Clinical and Operational Research program to increase the numbers of public health, academic, and clinical leaders to facilitate research and its application in public health and health care to respiratory diseases in various countries. The recent ATS/ERS research priorities publication did not address health disparities as one of the research priorities, but did state that the natural history of the disease should be studied with regard to race, sex, and SES. ${ }^{135}$ 
The Forum of International Respiratory Societies developed a guide on preventing and treating lung diseases, including COPD. ${ }^{136}$ Principal recommendations include increase public awareness, target environment and tobacco, increase public health and clinical research, and train more health care providers globally to deal with lung diseases. It also recommended developing cost-effective management protocols for COPD in low-income settings. The European COPD Coalition has published a call for action among countries in the European Union to better target COPD. ${ }^{137}$ Among multiple recommendations, it was stated that the European Union should support and initiate research on social and environmental determinants of health to better understand factors that increase the risk of developing COPD in Europe.

The WHO has a number of publications addressing COPD and SES including an essential medicine list, tobacco prevention strategies, guidelines to reduce indoor BF exposure, prevention of chronic respiratory tract diseases, and managing COPD in low SES settings. ${ }^{138-143}$ WHO recommendations for the diagnosis and management of COPD in low SES settings by primary care providers have been published. ${ }^{142}$ Considering the lack of availability of spirometry in many low-income settings, WHO recommends the use of clinical history and peak expiratory flow measurement to guide the diagnosis of COPD. Severity of COPD is judged based on symptoms. Education of the patient and family is recommended regarding biomass fuels, occupational exposures, and tobacco smoke. Recommended drug therapies included short-acting $\beta 2$-agonists and low dose oral theophylline. They also state that ipratropium may be an option, but may be too expensive. ${ }^{142}$ Regarding tobacco, WHO embraces the MPOWER acronym approach for tobacco: Monitor tobacco use and prevention policies, Protect people from tobacco smoke, Offer help to quit tobacco use, Warn about the dangers of tobacco, Enforce bans on tobacco advertising, promotion, and sponsorship, and lastly Raise taxes on tobacco. ${ }^{139}$ Goals of the WHO Strategy for Prevention and Control of Chronic Respiratory Diseases are to improve 1) surveillance to map and analyze the determinants with particular reference to poor and disadvantaged populations and to monitor the future trends, 2) primary prevention to reduce the level of exposure of individuals and populations, and 3) secondary and tertiary prevention to strengthen health care for people with chronic respiratory diseases. ${ }^{141} \mathrm{WHO}$ also provides a list of essential medicines for many diseases that is updated every 2 years. ${ }^{138}$ Additionally, the WHO has begun a noncommunicable chronic diseases monitoring system for $>190$ countries. ${ }^{143}$

\section{Surveillance}

Opportunities for surveillance include expanding epidemiologic studies in more low SES settings and using these data to aid efforts such as to screen for undiagnosed disease. Despite the tremendous global burden of chronic respiratory disease, there are relatively limited data on its prevalence, natural history, and associated morbidity and mortality of COPD in LMICs. ${ }^{144}$ However, there has been significant progress in defining the prevalence and impact of COPD globally through surveillance studies - particularly with the newer BOLD and PLATINO international studies, additional studies in Africa, ${ }^{145}$ and in the US with the expansion of the Behavioral Risk Factor Surveillance System for COPD prevalence. ${ }^{146,147}$

Ideally, each surveillance system should be capable of describing disease prevalence and disease impact in disparate people as well as the overall population. Furthermore, the information must be communicated to appropriate people including policy makers, health care providers, and the population from which the data were derived. This is largely a role of the public health sector in collaboration with others involved in health care provision. In general, the lay public's knowledge of COPD is far less than that of other diseases such as asthma, cancer, and heart diseases, ${ }^{148,149}$ therefore, it is imperative to educate the general public about COPD, partially relying on these surveillance data. Ideally, this education should occur throughout the population including the educational systems of young people.

One proposed strategy is to provide annual reports on lung health surveillance data from vulnerable, disparate populations. ${ }^{150}$ The WHO has recently begun a multinational surveillance of chronic diseases to better monitor low SES populations. ${ }^{143}$ In the US, a Nationwide Framework for Surveillance of Cardiovascular and Chronic Lung Diseases recommends to provide such data through surveillance to analyze disparities in disease prevalence, risk factors, outcomes, and health care delivery. It was recommended to integrate various surveillance systems into a central system that is able to function nationally and locally. ${ }^{151}$ In addition to the use of the Behavioral Risk Factor Surveillance System health survey, the US Centers for Disease Control and Prevention also recently expanded surveillance for COPD through the use of chronic disease indicators. ${ }^{152}$ The chronic disease indicators are used by epidemiologists at local, state, and national levels in the US to monitor many major chronic diseases. The updated indicators are 1) mortality of COPD as a primary or secondary cause, 2) COPD prevalence, 3) ED visits with COPD as a primary or secondary cause, and 4) 
hospitalizations as a primary or secondary cause. Previously, only mortality was included in these measures; inclusion of COPD as comorbidity in surveillance of other diseases will provide greater perspective of its impact across health care.

\section{Primary prevention}

Of all possible interventions, primary prevention for COPD through the avoidance of exposure to inhalant toxins would have the most impact on this disease; however, this is difficult to achieve in disadvantaged people. Both strategies and interventions are necessary to target low SES communities by improving housing conditions, providing education on tobacco in people at a young age, reducing tobacco use, and reducing other detrimental environment exposures, however, interventions are not often implemented.

To have an impact on tobacco use in the low SES population, it will require societal changes and efforts by health care organizations, public health, and individual providers. Societal interventions that can impact tobacco use include raising taxes on cigarettes, banning the use of tobacco in certain settings such as health care facilities, schools, government facilities, restaurants, and bars, and restricting advertisement. ${ }^{100} \mathrm{~A}$ study conducted in one US state showed that communities with smoke-free public policies had significantly lower rates of COPD hospitalizations. ${ }^{153}$ A recent Cochrane Review reported that national smoking bans in 21 countries led to improvement in multiple outcome measures. ${ }^{154}$ Because people who are more educated smoke tobacco at much lower rates, it is logical that improving secondary and tertiary education programs for the low SES population would contribute significantly to lower smoking rates. Education access and performance are heavily determined by family background, including family income and environment, which can strongly influence cognitive and noncognitive abilities.

As a whole, health care providers perform suboptimally in assisting patients to quit smoking. A 2007 report by the American Association of Medical Colleges on physician behavior showed that most physicians consistently ask patients about their smoking status and advise them to stop (86\%) if a smoker, but steps afterward were infrequent. ${ }^{155}$ Physicians indicated the tools, training, and resources to aid patients effectively in stopping smoking are inadequate.

There are limited studies evaluating smoking cessation interventions in low-income people. ${ }^{156,157}$ One study used a systematic, telephone-based intervention involving counseling, nicotine replacement therapy, and community resources, to double the quit rates $(17 \%$ vs $8 \%) .{ }^{156}$
Identifying and reaching out to poor people in their local communities was an important part of this program. In reality, typical interventions should be effective, but there is such a large number of smokers who are of low SES, and they are less inclined to quit, therefore the task is large. A national smoking cessation approach in Denmark was able to achieve reasonable abstinence rates in low SES people, however were still $30 \%$ lower in the low education vs the high education group. ${ }^{157}$

Perhaps idealistic, the best approach for a physician to effectively facilitate smoking cessation is as follows: 1) ensure determination of smoking status, 2) the provider and other team members advise smoker to quit, 3) if the patient is willing, the prescriber initiates further steps with a simple prescriptive order, where drug therapy and counseling resources are available and are provided directly to the patient thereafter, and 4) the provider sees the patient in follow-up. Unfortunately, there are multiple barriers inhibiting this optimistic model in many settings, much of it are resource based. Of note, the WHO essential medicine list includes nicotine replacement therapy. In the US, the cost of nicotine replacement therapy is comparable to the costs of smoking 20 cigarettes per day; therefore, cost of this therapy should be no different than that of smoking for most people.

Household air pollution is a modifiable exposure for which specific interventions such as the use of improved fuels (higher on the fuel ladder) for cook stoves, gas lighting, or heaters may be effective in lowering the risk of COPD. ${ }^{158}$ The WHO provides guidelines for lowering indoor exposure to burning BF. ${ }^{140}$ Some of the key recommendations include 1) exposure to fine particulate matter (PM 2.5) should not exceed $0.23 \mathrm{mg} / \mathrm{min}$ when unvented (eg, without a chimney or hood) and $0.80 \mathrm{mg} / \mathrm{min}$ when vented (eg, with a chimney or hood); 2) amount of carbon monoxide should not exceed $0.16 \mathrm{~g} / \mathrm{min}$ for unvented devices and $0.59 \mathrm{~g} / \mathrm{min}$ for vented devices; 3 ) unprocessed coal should not be used as an indoor fuel; and 4) kerosene should not be used as an indoor fuel. The WHO recommends biogas, ethanol, liquefied petroleum gas, and natural gas as safer alternative fuels. In addition to cleaner fuels, vented, more efficient biomass stoves might also serve to decrease indoor exposure. There is an international effort to bring safer BF in homes by the UN Foundation Global Alliance for Clean Cookstoves and the Climate and Clean Air Coalition. ${ }^{159}$ Unfortunately, the less expensive fuel options are generally less efficient fuels, produce more smoke, and are used by people with the most poorly designed homes. Cleaner fuels such as propane or liquid petroleum 
gas burn very cleanly, but are often too expensive for many impoverished households.

A number of studies show that reducing BF exposures improves respiratory outcomes. In 2011, a randomized, controlled study (RESPIRE 6) showed that a reduction in disease activity is possible - in this case, there was a decrease in severe pneumonia in children after a chimney stove intervention to reduce indoor air pollution. ${ }^{160}$ Romieu et al conducted a trial in $>500$ Mexico women to evaluate the effect of a chimney wood stove intervention vs the traditional open fire stove on respiratory symptoms and lung function. ${ }^{161}$ Although the adherence was poor (50\%), use of the chimney stoves reduced respiratory symptoms (rate ratio of 0.29 for wheezing) and decline in lung function (31 vs $62 \mathrm{~mL}$ ) over a 1-year period compared with those using open fire. ${ }^{161}$ In another study, investigators from the People's Republic of China followed participants for up to 9 years and found that using biogas instead of biomass for cooking reduced the annual decline of $\mathrm{FEV}_{1}$ by $12 \mathrm{~mL}$ per year and improved kitchen ventilation reduced the decline by $13 \mathrm{~mL}$ per year, compared with those who took up neither intervention. ${ }^{162}$ One study in Columbia, South America, showed that conversion to natural gas heating led to a reduction in outpatient visits and hospitalizations for COPD. ${ }^{163}$ In the US, the Environmental Protection Agency has new recommendations on indoor wood stoves to decrease particulate emissions. ${ }^{164}$

Although ambient air pollution has well-documented the adverse effects on patients with COPD, the evidence for air pollution as a cause of COPD is inconclusive. ${ }^{87} \mathrm{~A}$ study before and during the 2008 Beijing Olympics showed that the risk of asthma outpatient visits declined with lower ozone levels that occurred with changes in automobile use and manufacturing preceding and during the games. ${ }^{165}$ Regarding air pollution, minimizing exposure on poor air quality periods may aid in lessening the symptoms or preventing the exacerbations in COPD patients. Therefore, having daily, easily accessible air quality reports to the general population including people with lung disease is valuable, particularly for those with severe disease.

Prevention through appropriate immunizations can improve outcomes in the COPD population from influenza and pneumococcus infections. ${ }^{166}$ Pertussis can be associated with AECOPD, ${ }^{167}$ but there is no evidence that vaccination can decrease the risk of AECOPD. Like many other aspects of health care in low SES, immunizations are less likely to be administered appropriately in disadvantaged people in most, ${ }^{168,169}$ but not in all settings. ${ }^{170}$ Countries with fully funded immunization programs have higher rates of utilization. ${ }^{170}$

\section{Health care access}

Access to health care is a common barrier to good health in disadvantaged people because of the lack of resources and local availability of primary care and specialists. This is particularly true in rural areas, where a significant segment of the COPD population resides. Too often, care for disadvantaged people occurs in EDs, where care is very costly and not optimal as the principal site of health care for COPD patients. In the UK, a survey showed that the majority of patient contact with health services occurs via either the general practitioner or an emergency admission to hospital. ${ }^{171}$ The development of a National Service Framework for COPD in the UK has set goals to improve the quality and access to COPD services as well as to reduce inequalities and health care utilization costs. ${ }^{172}$ A study by Lisspers et al in Sweden showed that incorporating specialist nurses in asthma/COPD clinics decreased AECOPD in patients without additional secondary specialist care. ${ }^{173}$ Researchers from Plymouth University in the UK are undertaking a project in several LMICs to improve access to health care to prevent and manage chronic lung diseases including nontraditional pulmonary rehabilitation clinics, smoking cessation programs, and involving local midwives. ${ }^{174}$ The project, FRESH AIR, will adapt and test innovative ways to implement evidence-based practice in the prevention, diagnosis, and treatment of chronic lung disease in several LMICs. A study in Pakistan plans to target low resource settings using various approaches such as providing COPD care in the existing tuberculosis clinics. ${ }^{175}$

Studies looking at the impact of telemedicine have been equivocal in improving access to health care and outcomes in COPD. ${ }^{176}$ Telemedicine is more challenging in low SES people for various reasons. For example, the poor and elderly tend to use cheaper, less "smart" phones, and therefore, technology may not be compatible with the COPD patients' technological capabilities.

Educating more respiratory specialists, including minority providers, is needed as rural and poor areas lack pulmonary specialists in many countries. Little has been published regarding the geographic distribution of specialists and therefore availability of care for low SES COPD patients. ${ }^{8}$ The ATS, ERS, and Forum of International Respiratory Societies support better education and availability of providers available to COPD patients. They want to ensure that medical and other health care students are taught about the association between COPD and SES. Postgraduate education regarding disparities is also needed at multi- and interdisciplinary conferences for health care 
providers, public health practitioners, health agencies, and others in every country to address SES and lung diseases in an ongoing basis.

\section{Screening and diagnosis}

Since the majority of people with undiagnosed COPD have low SES, undertaking population screening or case-finding in targeted communities or health care settings is desirable. There are a number of screening and case-finding questionnaires that can identify people at high risk of COPD. ${ }^{177-181}$ Although smoking history is always addressed, most do not include questions about BF or occupational exposures. ${ }^{183}$ A COPD screening questionnaire was developed in the People's Republic of China, which included both smoking and exposure to BF from cooking but did not include occupational exposures. ${ }^{181}$ The BOLD and PLANTINO studies' questionnaires included occupational exposures and smoking history, but not BF. ${ }^{62,182}$ To make COPD case-finding or population screening most applicable globally, it is imperative to develop and validate such questionnaires that include all three major categories of COPD risk factors - tobacco, occupation, and $\mathrm{BF}$ exposures. In general, the sensitivity of such screening/ case-finding questionnaires can be improved with portable flow meters that measure $\mathrm{FEV}_{1}$ and $\mathrm{FEV}_{6}{ }^{183}$

Diagnostic resources for COPD in LMICs are poor; therefore, diagnoses are often made on the basis of clinical features alone, which is a distinct limitation for a disease that by the strictest definition requires documentation of AO. One Chinese study did use discriminant function analysis, not relying on spirometry, by using nine patient characteristics including smoking history, occupation, and rural vs urban residence, to screen for COPD in impoverished areas. The sensitivity was reported to be $\sim 90 \%$ based upon AO measured by spirometry. One study showed the benefits of screening for undiagnosed COPD in different socioeconomic practice settings. ${ }^{184}$

The WHO published specific guidelines to aid primary care providers in low-income populations for the diagnosis and management (Figure 2) of COPD. ${ }^{142}$ In situations where diagnostic spirometry is limited, WHO recommends to make a diagnosis based on age, clinical history (persistent respiratory symptoms and chronic productive cough), and exposure history ( $>1 \mathrm{ppd} \times 15$ years $)$. Although debatable, it was also recommended that peak flow meters can be used to determine AO reversibility and thus help differentiate between asthma and COPD. However, portable spirometers that can measure peak flows, $\mathrm{FEV}_{1}, \mathrm{FEV}_{6}$, and/or forced vital capacity are now fairly inexpensive.

\section{Treatment}

The care offered to low SES patients with chronic respiratory disease is not always based on research or best practices. Often, access to optimal COPD treatments, such as availability to primary and specialist providers, smoking cessation counseling, supplemental oxygen, and noninvasive ventilation, is limited in these people. The WHO published guidelines for the treatment of asthma and COPD by primary care providers in resource-limited settings. ${ }^{142}$ It was designed to aid easy access and facilitate implementation in busy community clinics and small hospitals. It provides recommendations for acute and chronic management of COPD. Patient education regarding preventive measures such as stopping smoking tobacco products, use of well-ventilated areas for cooking and heating, as well as awareness about high-risk occupations is recommended. The recommended drug therapies are few and by most developed country's standards would probably be considered to be suboptimal.

One important goal to optimally treat COPD patients is to properly diagnose and manage comorbidities common to this population. Early identification and optimal treatment of heart disease, lung cancer, depression, and obstructive sleep apnea can improve outcomes. Heart disease and lung cancers are more common in COPD, which more likely occur in low SES people. Cardio-selective B-blockers, when prescribed for some types of heart disease, reduce the overall mortality in COPD. ${ }^{185}$ Unfortunately, too often practitioners are reluctant to prescribe these agents for COPD, although the cardioselective agents have a low risk of worsening AO. ${ }^{186}$ These agents are available generically and are relatively affordable. In the US, low-dose chest CT screening has commenced in high-risk people to identify early lung cancer and decrease the associated mortality; however, this is quite expensive. ${ }^{187}$ Obstructive sleep apnea occurs in COPD at about the same rate as the comparable patients in general population but is more common in low SES patients. ${ }^{188}$ Patients with coexisting COPD and sleep apnea typically develop more severe oxygen desaturation during sleep and have worse outcomes. ${ }^{189}$ Treatment of severe obstructive sleep apnea is most effectively done with noninvasive ventilation, although costs may be prohibitive.

Efforts to educate the general public and COPD patients are sorely lacking, particularly for impoverished people. Only recently, education about COPD to the general public has been undertaken in the US, whereas much more has been done to educate the public about asthma. Education about smoking, BFs, and the disease COPD should start as early as primary schools; however, health literacy is a major issue 


\section{Management of exacerbation of COPD}

Antibiotics: should be given for AECOPD (strong recommendation, very low-quality evidence)

Oral steroids: a short course of prednisolone is recommended for severe AECOPD (eg, prednisolone 30-40 mg for about 7 days (strong recommendation, very low-quality evidence)

Inhaled beta agonists: higher doses of inhaled salbutamol should be administered via a nebulizer or spacer (strong recommendation, very low-quality evidence)

Oxygen: if available, oxygen should be administered by a device that controls concentration of $24 \%-28 \%$ (strong recommendation, very low-quality evidence)

Intravenous aminophylline: based on the available evidence, IV aminophylline not recommended in AECOPD. Little evidence of benefit; any beneficial effect is likely small and outweighed by ADRs (strong recommendation, very low-quality evidence)

\section{Stable management}

Short-acting beta-agonists: are effective in improving symptoms in patients with stable COPD. Prescribe as required. No data to assess the optimum frequency of administration or the effect of regular administration. Oral B-agonists not recommended (weak recommendation, very low-quality evidence)

Theophylline: unlikely that blood levels can be monitored in resource-constrained settings, only low doses of theophylline are recommended. Patients should be advised about ADRs (weak recommendation, very low-quality evidence)

Oral corticosteroids (prednisolone): are ineffective in stable COPD except possibly in high doses when there are important side effects. On the basis of benefits and risks, oral steroids are not recommended for use in stable COPD (strong recommendation, very low-quality evidence)

Inhaled steroids (beclomethasone): when given in high doses, there may be a small benefit from ICS; however, high doses are expensive for resource-poor countries and high doses have more ADRs, including pneumonia. Risks are unknown in areas where the prevalence of HIV and tuberculosis are high. Since the benefit is modest, the risk/benefit ratio is much higher than it is for asthma. The use of ICS for patients with stable COPD therefore cannot be justified. Not recommended (strong recommendation, very low-quality evidence)

Ipratropium bromide: when compared to regular short-acting beta agonists, short-term inhaled ipratropium bromide has small benefits in reducing symptoms and improving lung function. Currently, ipratropium preparations are more expensive than beta agonists, and there are no data to assess risk versus benefits of regular use over longer periods to recommend long-term regular use. Not recommended (weak recommendation, very low-quality evidence)

Figure 2 World Health Organization drug therapy guidelines for managing acute exacerbations of COPD and stable management in resource limited settings.

Note: Reprinted from World Health Organization. Prevention and control of non-communicable diseases: guidelines for primary health care in low-resource settings. Copyright 2012. ${ }^{142}$

Abbreviations: ADRs, adverse drug reactions; AECOPD, acute exacerbation of COPD; COPD, chronic obstructive pulmonary disease; HIV, human immunodeficiency virus; ICS, inhaled corticosteroid; IV, intravenous.

in some of these children and their families. Education about COPD and its risk factors should be culturally sensitive and at the appropriate education level for the target population. A study in a primary care setting showed that COPD patients with a high-school or less education, capable of communicating or writing, were able to be successfully educated about their disease. ${ }^{190}$

Poor access to medications and noncompliance are major factors that limit the optimal management of obstructive lung diseases. ${ }^{191,192}$ Identifying cost-effective drug therapy strategies will vary among different settings and countries; health care providers should explore what the options are in their local settings. Essentially, all evidence-based COPD medications are more limited in resource sparse settings and even the most basic medications have variable availability. This is true despite the overall cost-effectiveness of interventions such as smoking cessation counseling combined with drug therapy or maintenance drugs that can decrease AECOPD. It is well documented that maintenance medications for COPD can improve respiratory symptoms and quality of life and decrease $\mathrm{AECOPD}^{1}$ and that medication adherence can improve mortality. ${ }^{193}$ There is little definitive data supporting that these medications can modify the course of COPD; however, it could be a function of identifying phenotypes and genotypes with which drug therapies could slow down the progression of the disease and improve survival. Currently, interventions with the most mortality benefits relevant to COPD include 1) long-term supplemental oxygen, 2) smoking cessation, 3) lung transplantation, and 4) optimizing prevention or management of key comorbidities such as heart disease - the latter three include medications.

Annually, the WHO publishes an updated essential medicine list that includes the most basic drug therapies relevant to the acute and chronic management of COPD. ${ }^{194}$ Even for these therapies, disadvantaged persons have substantial challenges in accessing and paying for COPD medications as well as being adherent with their therapies. The most basic drug therapy, albuterol, can account for a high portion of personal income in LMICS, often as much as several days wages. ${ }^{144}$ In the US, drug costs can also be quite substantial for a person 
Table 5 Drug costs relative to days of work in low-income people in the US

\begin{tabular}{|c|c|c|c|c|}
\hline Measure & $\begin{array}{l}\text { Albuterol MDI } \\
\text { (200 inhalations) }\end{array}$ & ICS/LABA inhaler ${ }^{a}$ & LAMA inhaler ${ }^{\mathrm{a}}$ & $\begin{array}{l}\text { Albuterol + ICSI } \\
\text { LABA + LAMA }\end{array}$ \\
\hline Retail drug costs ${ }^{\mathrm{b}}$ & $\$ 55.00$ & $\$ 340.00$ & $\$ 320.00$ & $\$ 715.00$ \\
\hline $\begin{array}{l}\text { Days of work required to pay for } \\
\text { medication(s) using } \sim \text { minimum wage }\end{array}$ & 0.86 days & 5.3 days & 5 days & II.2 days \\
\hline
\end{tabular}

Notes: ${ }^{a}$ One month supply. ${ }^{b}$ Approximate retail costs with no subsidies were obtained from www.goodrx.com. Accessed February I, $2016 .{ }^{197}$ cAnnual income of $\$ 16,640$ (based on a minimum wage salary of $\$ 8 /$ hour at 40 hours/week).

Abbreviations: MDI, metered dose inhaler; ICS, inhaled corticosteroid; LABA, long-acting beta agonist; LAMA, long-acting antimuscarinic agent.

living in poverty. In an advanced COPD patient, a triple drug regimen could cost nearly half of a monthly personal income without health insurance subsidies (Table 5). Even when subsidized by insurers, the poor often choose between basic living necessities vs appropriately using their prescribed COPD medications. One strategy in the US to decrease drug costs for retired or disabled COPD patients, covered by the federal Medicare insurance program, is to prescribe nebulized albuterol, ipratropium, formoterol, arformoterol, and/or budesonide if they fail the same drugs through an inhaler. Different settings may have resources available to uniquely help lower the drug costs.

An important contributor to unaffordability of COPD medications is the lack of generic versions for the majority of drugs used to chronically manage COPD. In contrast, many of the prominent maintenance medications for cardiovascular diseases and other major chronic diseases often have cheaper generic drugs. In the US, this is affected by Food and Drug Administration requirements for new "generic" inhalers. Somewhat extensive and expensive studies are mandated for generic inhalers by the US Food and Drug Administration, often taking years to bring to market. The European Medicines Agency has less strict requirements to bring a generic inhaler to the market. It has been suggested that regulatory agencies among different countries share and accept submitted pharmaceutical company dossiers among themselves through harmonizing regulations. This has been the major impediment toward declaring a "global worldwide reference product" that generic pharmaceutical companies could use in their development. ${ }^{119}$

It is well-documented that people with low SES have significantly worse medication adherence, including for COPD. There are multiple contributors including commercial availability, costs, and health behaviors that affect adherence. Medication adherence is a function of numerous factors, and in general people of a low SES tend to be the most noncompliant. ${ }^{195}$ This is partially due to lack of resources in some people, however, occurs even in an insured indigent. In a study of a US health system in adults with health care insurance, it was found that medication adherence was poorest in people with low education level; and further patients with asthma or COPD had the worse adherence compared with chronic diseases such as depression and diabetes mellitus. ${ }^{31}$ In 2006, one study found that tiotropium was used less frequently in people with low vs high SES (odds ratio $=0.3$ ) ${ }^{46}$ whereas in another study albuterol use was prescribed more often in highly polluted areas where the poor live. ${ }^{131}$ An excellent review on access to essential medicines for obstructive lung diseases and related issues in disparate settings was published in 2015 by the Forum of International Respiratory Societies. ${ }^{196}$

\section{Conclusion}

Across the globe, COPD disproportionately affects ethnic minorities and low socioeconomic groups. Vulnerable populations have differential exposure to indoor and outdoor pollution, occupational and environmental hazards, and tobacco smoke, which contribute to disparities in prevalence of COPD and outcomes. However, social determinants of health (ie, access to health care, education, economic stability, social and community context, and neighborhood/built environment) add an additional barrier to establishing health equity. Consequently, interventions that are designed to improve health equity should be adapted for the socioeconomic and political context in which the vulnerable problems exist. Each setting, whether it is the individual clinic setting, health care system, community, region, and country, has its unique influences and resources that will determine the best approaches to lessen the burden of health disparities related to COPD. Whether it is at the health care provider-patient level, the health care organization level, or societal level - it has been and will continue to be a challenge to lessen the disparities associated with COPD and SES, if no other reason, the availability of adequate resources. No one sector will solve the issues with disparities regarding COPD. Eventually, COPD will be a disease of predominantly the low SES segment of the population, whether caused by tobacco or biomass or occupation. The question is going to be how significant a role the disease plays, which depends on resources, programmatic approaches, and individual health 
care and public health providers and societies. However, when it comes to health care costs, being poor is expensive. We have largely "diagnosed the syndrome of health disparities in COPD", and evidence-based strategies that address SES are greatly needed to decrease disease burden.

\section{Disclosure}

The authors report no conflicts of interest in this work.

\section{References}

1. Global Initiative for Chronic Obstructive Lung Disease. Guidelines: Summarising clinical guidelines for primary care. COPD diagnosis, management and prevention. Available from: https://www.guidelines. co.uk/gold/copd. Accessed March 8, 2016.

2. Gershon AS, Dolmage TE, Stephenson A, Jackson B. Chronic obstructive pulmonary disease and socioeconomic status: a systematic review. COPD. 2012;9:216-226.

3. Holloway JW, Arshad SH, Holgate ST. Using genetics to predict the natural history of asthma. J Allergy Clin Immunol. 2010;126:200-209.

4. Siedlinski M, Michael H, Cho MH, et al. Genome-wide association study of smoking behaviors in COPD patients. Thorax. 2011;66:894-902.

5. World Health Organization. Chronic obstructive pulmonary disease (COPD); Fact sheet; March 2015. Available from: https://www.who. int/mediacentre/factsheets/fs315/en/. Accessed January 23, 2016.

6. Healthy People 2020; Office of Disease Prevention and Health Promotion; US Department of Health and Human Services. Phase I Report: Recommendations for the Framework and Format of Healthy People 2020. Section IV. Advisory Committee Findings and Recommendations. Available from: https://www.healthypeople.gov/2020/about/advisory/ Reports. Accessed January 23, 2016.

7. World Health Organization. The economics of social determinants of health and health inequalities: a resource book. Available from: http:// apps.who.int/iris/handle/10665/84213. Accessed January 23, 2016.

8. Schraufnagel DE, Blasi F, Kraft M, et al. An official American Thoracic Society/European Respiratory Society policy statement: disparities in respiratory health. Am J Respir Crit Care Med. 2013;188:865-871.

9. World Health Organization health topics - poverty. World Health Organization. Available from: http://www.who.int/topics/poverty/en/. Accessed January 23, 2016.

10. Lewis DR, Clegg LX, Johnson NJ. Lung disease mortality in the United States: the National Longitudinal Mortality Study. Int J Tuberc Lung Dis. 2009;13:1008-1014.

11. Steenland K, Hu S, Walker J. All-cause and cause-specific mortality by socioeconomic status among employed persons in 27 US states, 1984-1997. Am J Public Health. 2004;94:1037-1042.

12. Forno E, Celedon JC. Health disparities in asthma. Am J Respir Crit Care Med. 2012;185:1033-1035.

13. Crocker D, Brown C, Moolenaar R, et al. Racial and ethnic disparities in asthma medication usage and health-care utilization. Chest. 2009; 136:1063-1071.

14. Pleasants R, Ohar J, Croft JB, et al. Chronic obstructive pulmonary disease and asthma - patient characteristics and health impairment. COPD. 2014;7:1-11.

15. World Health Organization. Commission on social determinants of health - final report. Closing the gap in a generation: health equity through action on the social determinants of health. Available from: http://www. who.int/social_determinants/thecommission/finalreport/en/. Accessed January 23, 2016.

16. Whitehead M. The concepts and principles of equity and health. Health Promotion Int. 1991;6:217-228.

17. Trinder PM, Croft PR, Martyn Lewis M. Social class, smoking and the severity of respiratory symptoms in the general population. J Epidemiol Comm Health. 2000;54:340-343.
18. Shohami S, Welch A, Bingham S, et al. Area deprivation predicts lung function independently of education and social class. Eur Respir J. 2004:24:157-161.

19. Welle I, Eide GE, Gulsvik A, Bakke PS. Pulmonary gas exchange and educational level: a community study. Eur Respir J. 2004;23:583-588.

20. Schikowski T, Sugiri D, Reimann V, Pesch B, Ranft U, Kramer U. Contribution of smoking and air pollution exposure in urban areas to social differences in respiratory health. BMC Public Health. 2008;8:179.

21. Smith M, Li L, Augustyn M, Kurmi O. Prevalence and correlates of airflow obstruction in $\sim 317,000$ never-smokers in China. Eur Respir $J$. 2014;44:66-77.

22. Kurmi OP, Li L, Wang J, et al. COPD and its association with smoking in the mainland China: a cross-sectional analysis of 0.5 million men and women from ten diverse areas. Int J Chron Obstruct Pulmon Dis. 2015; 10:655-665.

23. Liu Y, Pleasants RA, Croft J, et al. Smoking duration, respiratory symptoms, and COPD in adults aged $\geq 45$ years with a smoking history. Int J Chron Obstruc Pulmon Dis. 2015;10:1-8.

24. Bakke PS, Baste V, Hanoa R, Gulsvik A. Prevalence of obstructive lung disease in a general population: relation to occupational title and exposure to some airborne agents. Thorax. 1991;46:863-870.

25. Eachus J, Williamw M, Chan P, et al. Deprivation and cause specific morbidity: evidence from the Somerset and Avon survey of health. BMJ (Clin Res). 1996;212:287-292.

26. Chen Y, Breithaupt K, Muhajarine N. Occurrence of chronic obstructive pulmonary disease among Canadians and sex-related factors. J Clin Epidemiol. 2000;53:755-761.

27. Marmot M, Shipley M, Brunner E, et al. Relative contribution of early life and adult socioeconomic factors to adult morbidity in the Whitehall II study. J Epidemiol Commun Health. 2001;55: 301-307.

28. Montnemery P, Bengtsson P, Elliott A, et al. Prevalence of obstructive lung diseases and respiratory symptoms in relation to living environment and socio-economic group. Respir Med. 2001;95:744-752.

29. Lindberg A, Jonnson AC, Ronmark E, et al. Ten-year cumulative incidence of COPD and risk factors for incident disease in a symptomatic cohort. Chest. 2005;127:1544-1552.

30. Ellison-Loschmann L, Sunyer J, Plana E, et al. Socioeconomic status, asthma, and chronic bronchitis in a large community-based study. Eur Respir J. 2007;29:897-905.

31. Eisner MD, Blanc PD, Omachi TA, et al. Socioeconomic status, race, and COPD health outcomes. J Epidemiol Commun Health. 2011;65: 26-34.

32. Halvorsen T, Matrinussen PA. The geography of chronic obstructive pulmonary disease: a population-based study of Norway. Soc Sci Med. 2014;111:25e34.

33. Karnevisto M, Vasankari T, Laitinen T, et al. Low socioeconomic status is associated with chronic obstructive airway diseases. Respir Med. 2011;105:1140-1146.

34. Lovasi GS, Diex Roux AV, Hoffman EA, et al. Socioeconomic status is positively associated with percent emphysema on CT scan: the MESA lung study. Acad Radiol. 2011;18:199-204.

35. Yin P, Zhang M, Li Y, et al. Prevalence of COPD and its association with socioeconomic status in China: findings from China chronic disease factor surveillance 2007. BMC Public Health. 2011;11:586.

36. Herrick H, Pleasants R, Wheaton A, et al. Chronic obstructive pulmonary disease and associated health-care resource use - North Carolina 2007 and 2009. Morbid Mortal Wkly Rep. 2012;61:143-146.

37. Kainu A, Rouhos A, Sovijarvi A, et al. COPD in Helinski, Finland: socioeconomic status based on occupation has an important impact on prevalence. Scand J Public Health. 2013;41:570-578.

38. Golec M, Skorska C, Mackiewicz B, et al. Relationship between COPD and lower socioeconomic status in farmers from south-eastern Poland (Lublin region). Rural Remote Health. 2014;14:2531.

39. Hagstad S, Backman H, Anders Bjerg A, et al. Prevalence and risk factors of COPD among never-smokers in two areas of Sweden: occupational exposure to gas, dust or fumes is an important risk factor. Respir Med. 2015;109:1439e1445. 
40. Lee SJ, Kim SW, Kong KA, et al. Risk factors for chronic obstructive pulmonary disease among never-smokers in Korea. Int J Chron Obstruct Pulmon Dis. 2015;10:497-506.

41. Tan WC, Sin DD, Bourbeau J, et al. Characteristics of COPD in neversmokers and ever-smokers in the general population: results from the CanCOLD study. Thorax. 2015;70:822-829.

42. Van Rossum CT, Shipley MJ, van de Mheen H, et al. Employment grade differences in cause specific mortality. A 25 year followup of civil servants from the first Whitehall study. J Epidemiol Commun Health. 2000;54:178-184.

43. Prescott E, Godtferden N, Vestbo J, Osler M. Social position and mortality from respiratory diseases in males and females. Eur Respir J. 2003;21:821-826.

44. Huisman M, Kunst AE, Bopp M, et al. Educational inequalities in cause-specific mortality in middle-aged and older men and women in eight western European populations. Lancet. 2005;365:493-500.

45. Antonelli-Incazi R, Ancona C, Forastiere F, et al. Socioeconomic status and hospitalization in the very old: a retrospective study. BMC Public Health. 2007;7:227.

46. Blanc PD, Eisner MD, Yelin EH, et al. Socioeconomic gradients in tiotropium use among adults with COPD. Int J Chron Obstruct Pulmon Dis. 2008;3:483-490.

47. Reilly KH, Gu D, Duan X, et al. Risk factors for chronic obstructive pulmonary disease mortality in Chinese adults. Am J Epidemiol. 2008;167: 998-1004.

48. Schane RE, Walter LC, Dinno A, Covinsky KE, Woodruff PG. Prevalence and risk factors for depressive symptoms in persons with chronic obstructive pulmonary disease. J Gen Intern Med. 2008;23. 1757-1762.

49. Wong AWM, Gan WQG, Burns J, et al. Acute exacerbation of chronic obstructive pulmonary disease: influence of social factors in determining length of hospital stay and readmission rates. Can Respir J. 2008; $15: 361-364$.

50. Arne M, Lundin F, Boman G, Janson C, Janson S, Emtner M. Factors associated with good self-rated health and quality of life in subjects with self-reported COPD. Int J Chron Obstruct Pulmon Dis. 2011;6: 511-519.

51. Calderón-Larrañaga A, Carney L, Soljak M. Association of population and primary healthcare factors with hospital admission rates for chronic obstructive pulmonary disease in England: national cross-sectional study. Thorax. 2011;66:191-196.

52. Miravitlles M, Naberan K, Cantoni J, Azpeitia A. Socioeconomic status and health-related quality of life of patients with chronic obstructive pulmonary disease. Respiration. 2011;82:402-408.

53. Omachi TA, Sarkar U, Yelin EH, et al. Lower health literacy is associated with poorer health status and outcomes in chronic obstructive pulmonary disease. J Gen Intern Med. 2012;28:74-81.

54. McAllister DA, Morling JR, Fischbacher CM. Socioeconomic deprivation increases the effect of winter on admissions to hospital with COPD: retrospective analysis of 10 years of national hospital data. Prim Care Res J. 2013;22:296-299.

55. Gershon AS, Hwee J, Victor JC, Wilton AS, To T. Trends in socioeconomic status-related differences in mortality among people with chronic obstructive pulmonary disease. Ann Am Thorac Soc. 2014;11: 1195-1202.

56. Lange P, Marott JL, Vestbo J, et al. Socioeconomic status and prognosis in Denmark. COPD. 2014;11:431-437.

57. Trachtenberg AJ, Dik N, Chateau D, et al. Inequities in ambulatory care and the relationship between socioeconomic status and respiratory hospitalizations: a population-based study of a Canadian city. Ann Fam Med. 2014;12:402-407.

58. Sharma G, Meena R, Goodwin J, et al. Burn injury associated with home oxygen use in patients with chronic obstructive pulmonary disease. Mayo Clin Proc. 2015;90:492-499.

59. Brown CA, Crombie AK, Tunstall-Pedoe H. Failure of cigarette smoking to explain international differences in mortality from chronic obstructive pulmonary disease. J Epidemiol Community Health. 1994;48:134-139.
60. Burney P, Jithoo, Kato B, et al. Chronic obstructive pulmonary disease mortality and prevalence: the associations with smoking and poverty - a BOLD analysis. Thorax. 2014;69:465-473.

61. Camp PG, Alejandra Ramirez-Venegas A, Sansores RH, et al. COPD phenotypes in biomass smoke-versus tobacco smoke-exposed Mexican women. Eur Respir J. 2014;43:725-734.

62. Menezes AMB, Perez-Padilla R, Roberto J, et al. Chronic obstructive pulmonary disease in five Latin American cities (the PLATINO study): a prevalence study. Lancet. 2005;366:1875-1881.

63. Pleasants R, Ohar J, Croft JB, et al. Chronic obstructive pulmonary disease and asthma - patient characteristics and health impairment. J Chron Obstruct Pulmon Dis. 2014;7:1-11.

64. Kosacz N, Punturieri A, Croxton TL, et al. Chronic obstructive pulmonary disease among adults - United States, 2011. Morb Mortal Wkly Rep. 2012;61:938-943.

65. Yin $\mathrm{P}$, Jiang $\mathrm{C}$, Cheng $\mathrm{K}$, et al. Passive smoking exposure and risk of COPD among adults in China: the Guangzhou Biobank Cohort Study. Lancet. 2007;370:751-757.

66. Aguku IT, King BA, Dube SR. Current cigarette smoking among adults - United States 2005-2012. MMWR Morb Mortal Wkly Rep. 2014;63:29-34.

67. Twyman L, Bonevski B, Paul C, Bryant J. Perceived barriers to smoking cessation in selected vulnerable groups: a systematic review of the qualitative and quantitative literature. Br Med J Open. 2014;4:e006414.

68. Batra V, Patkar AA, Berrettini WH, et al. The genetic determinants of smoking. Chest. 2003;123:1730-1739.

69. Jaganath D, Miranda JJ, Gilman RH, et al. Prevalence of chronic obstructive pulmonary disease and variation in risk factors across four geographically diverse resource-limited settings in Peru. Respir Res. 2015;16:40.

70. Balmes JR. Occupational contribution to the burden of chronic obstructive pulmonary disease. J Occup Environ Med. 2005;47;154-160.

71. Trupin L, Earnest G, San Pedro M, et al. The occupational burden of chronic obstructive pulmonary disease. Eur Respir J. 2003;22:462-469.

72. de Meer G, Kerkhof M, Kromhout H, Schouten JP, Heederik D. Interaction of atopy and smoking on respiratory effects of occupational dust exposure: a general population-based study. Environ Health. 2004;3:6.

73. Weinmann S, Vollmer WM, Breen V, et al. COPD and occupational exposures: a case-control study. J Occup Environ Med. 2008;50: 561-569.

74. Hnizdo E, Sullivan PA, Bang KM, Wagner G. Association between chronic obstructive pulmonary disease and employment by industry and occupation in the US population: a study of data from the third National Health and Nutrition Examination Survey. Am J Epidermiol. 2002;156:738-746.

75. Mehta AJ, Miedinger D, Keidel D, et al. Occupational exposure to dusts, gases, and fumes and incidence of chronic obstructive pulmonary disease in the Swiss Cohort Study on air pollution and lung and heart diseases in adults. Am J Respir Crit Care Med. 2012;185: $1292-300$

76. World Health Organization. Household air pollution and health fact sheet $N^{\circ} 292$; February 2016. Available from: http://www.who.int/ mediacentre/factsheets/fs292/en/. Accessed March 15, 2016.

77. Salvi S, Barnes P. Is exposure to biomass smoke the biggest risk factor for COPD globally? Chest. 2010;138:3-6.

78. Torres-Duque C, Maldonado D, Perez-Padilla R, Ezzati M, Viegi G. Biomass fuels and respiratory diseases: a review of the evidence. Proc Am Thorac Soc. 2008;5:577-590.

79. Viegi G, Simoni M, Scognamiglio A, et al. Indoor air pollution and airway disease. Int J Tuberc Lung Dis. 2004;8:1401-1415.

80. Liu S, Zhou Y, Wang X, et al. Biomass fuels are the probable risk factor for chronic obstructive pulmonary disease in rural South China. Thorax. 2007;62:889-897.

81. Orozco-Levi M, Garcia-Aymerich J, Villar J, et al. Wood smoke exposure and risk of chronic obstructive pulmonary disease. Eur Respir J. 2006;27:542-546. 
82. Zhang JJ, Smith KR. Household air pollution from coal and biomass fuels in China: measurements, health impacts, and interventions. Environ Health Perspect. 2007;115:848-855.

83. Zhou Y, Zou Y, Li X, et al. Lung function and incidence of chronic obstructive pulmonary disease after improved cooking fuels and kitchen ventilation: a 9-year prospective cohort study. PLoS Med. 2014;11:e1001621.

84. Kurmi OP, Semple S, Simkhaha P, Smith WCS, Ayres JG. COPD and chronic bronchitis risk of indoor air pollution from solid fuel: a systematic review and meta-analysis. Thorax. 2010;65:221-228.

85. Liu Y, Lee K, Perez-Padilla R, Hudson NL, Mannino DM. Outdoor and indoor air pollution and COPD-related diseases in high- and low-income countries. J Int Tuberc Lung Dis. 2012;12:115-127.

86. Sint T, Donohue JF, Ghio AJ. Ambient air pollution particles and the acute exacerbation of chronic obstructive pulmonary disease. Inhal Toxicol. 2008;20:25-29.

87. Sunyer J, Schwartz J, Tobias A, Macfarlane D, Garcia J, Anto JM. Patients with chronic obstructive pulmonary disease are at increased risk of death associated with urban particle air pollution: a casecrossover analysis. Am J Epidemiol. 2000;151:50-56.

88. Po JY, FitzGerald JM, Carlsten C. Respiratory disease associated with solid biomass fuel exposure in rural women and children: systematic review and meta-analysis. Thorax. 2011;66:232-239.

89. Hu G, Zhou Y, Tian Y, et al. COPD from exposure to biomass fuel: a meta-analysis. Chest. 2010;138:20-31.

90. Sood A, Petersen H, Blanchette CM, et al. Wood smoke exposure and gene promoter methylation are associated with increased risk for COPD in smokers. Am J Respir Crit Care Med. 2010;182:1098-1104.

91. Kim C, Chapman RS, Hu W, et al. Smoky coal, tobacco smoking, and lung cancer risk in Xunwei, China. Lung Cancer. 2014;84:31-35.

92. Boehmer TK, Foster SL, Henry JR et, Woghiren-Akinnifesi EL, Yip FY. Residential proximity to major highways - United States, 2010. MMWR. 2013;62(03)[Suppl]:46-50.

93. Schultz ES, Hallberg J, Bellander T, et al. Early-life exposure to traffic-related air pollution and lung function in adolescence. Am J Respir Crit Care Med. 2016;193:171-177.

94. Schikowski T, Mills IC, Anderson HR, et al. Ambient air pollution: a cause of COPD? Eur Respir J. 2014;43:250-263.

95. Turner S, Prabhu N, Daneilan P, et al. First- and second-trimester fetal size and asthma outcomes at 10 years of age. Am J Respir Crit Care Med. 2011;184:407-413.

96. Young S, Arnott J, O’Keeffe PT, Le Souef PN, Landau LI. The association between early life lung function and wheezing during the first 2 yrs of life. Eur Respir J. 2000;15:151-157.

97. Tager IB, Hanrahan JP, Tosteson TD, et al. Lung function, pre- and post-natal smoke exposure, and wheezing in the first year of life. Am Rev Respir Dis. 1993;147:811-817.

98. Håland G, Carlsen KC, Sandvik L. Reduced lung function at birth and the risk of asthma at 10 years of age. $N$ Engl J Med. 2006;355: 1682-1689.

99. Johannessen A, Bakke PS, Hardie JA, Eagan TM. Association of exposure to environmental tobacco smoke in childhood with chronic obstructive pulmonary disease and respiratory symptoms in adults. Respirology. 2012;17:499-505.

100. US Department of Health and Human Services. The health consequences of smoking - 50 years of progress: a report of the Surgeon General; 2014. Available from: http://www.surgeongeneral.gov/ library/reports/50-years-of-progress/. Accessed January 23, 2016.

101. Delpisheh A, Kelly Y, Rizwan S, Brabin BJ. Socio-economic status, smoking during pregnancy and birth outcomes: an analysis of crosssectional community studies in Liverpool (1993-2001). J Child Health Care. 2006;10:140-148.

102. Prabhu N, Smith N, Campbell D, et al. First trimester maternal tobacco smoking habits and fetal growth. Thorax. 2010;65:235-240.

103. Eisner MD, Balmes J, Katz PP, Trupin L, Yelin EH, Blanc PD. Lifetime environmental tobacco smoke exposure and the risk of chronic obstructive pulmonary disease. Environ Health. 2005;4:7.
104. Berend N. Contribution of air pollution to COPD and small airway dysfunction. Respirology. 2016;21:10.

105. Sunyer J. Urban air pollution and chronic obstructive pulmonary disease: a review. Eur Respir J. 2001;17:1024-1033.

106. Ko FW, Hui DS. Air pollution and chronic obstructive pulmonary disease. Respirology. 2012;17:395-401.

107. Lange P, Celli B, Agusti A, et al. Lung-function trajectories leading to chronic obstructive pulmonary disease. $N$ Engl J Med. 2015;373: $111-122$.

108. Svanes C, Sunyer S, Plana E, et al. Early life origins of chronic obstructive pulmonary disease. Thorax. 2010;65(1):14-20.

109. Tennant PWE, Gibson GJ, Parker L, Pearce MS. Childhood respiratory illness and lung function at ages 14 and 50 years: childhood respiratory illness and lung function. Chest. 2010;137(1):146-155.

110. de Marco R, Accordini S, Marcon A, et al. Risk factors for chronic obstructive pulmonary disease in a European cohort of young adults. Am J Respir Crit Care Med. 2011;183:891-897.

111. Tagiyeva N, Deveruex G, Fiedling S, et al. Outcomes of childhood asthma and wheezy bronchitis a 50-year cohort study. Am J Respir Crit Care Med. 2016;193:23-30.

112. Feinstein JS. The relationship between socioeconomic status and health; a review of the literature. Milbank Q. 1993;71:279-322.

113. Mackenbach J, Stronks K, Kunst AE. The contribution of medical care to inequalities in health. Soc Science Med. 1989;29:369-376.

114. Krishman JA. Race and sex differences in consistency of care with national asthma guidelines in managed care organizations. Arch Intern Med. 2001;161:1660-1668.

115. Gray AM. Inequalities in health. The Black Report: a summary and comment. Int J Health Serv. 1982;12:349-380.

116. Veugelers P, Yip A. Socioeconomic disparities in health care use: does universal coverage reduce inequalities in health? J Epidemiol Commun Health. 2003;57:424-428.

117. Cokkinides VE, Halpern MT, Barbeau EM, et al. Racial and ethnic disparities in smoking-cessation interventions: analysis of the 2005 national health interview survey. Am J Prev Med. 2008;34: 404- 412.

118. Browning KK, Ferketich AK, Salsberry PJ, et al. Socioeconomic disparity in provider-delivered assistance to quit smoking. Nicotine Tob Res. 2008;10:55-61.

119. Al-Numani D, Colucci P, Ducharme MP. Rethinking bioequivalence and equivalence requirements of orally inhaled drug products. Asian J Pharm Sci. 2015;10:461-471.

120. Montaño M, Beccerril C, Ruiz V, Ramos C, Sansores RH, GonzálezAvila G. Matrix metalloproteinases activity in COPD associated with wood smoke. Chest. 2004;125:466-472.

121. Moran-Mendoza O, Pérez-Padilla JR, Salazar-Flores M, VazquezAlfaro F. Wood smoke-associated lung disease: a clinical, functional, radiological and pathological description. Int J Tuberc Lung Dis. 2008; 12:1092-1098

122. Perez-Padilla R, Ramirez-Venegas A, Sansores-Martinez R. Clinical characteristics of patients with biomass smoke-associated COPD and chronic bronchitis. J Chron Obstruct Pulm Dis. 2014;1:23-32.

123. Gonzalez-Garcia M, Tores-Duque CA, Bustos A, et al. Bronchial hyperresponsiveness in women with chronic obstructive pulmonary disease. Int J Chron Obstruc Pulmon Dis. 2012;7:367-373.

124. Ramirez-Venegas A, Sansores RH, Perez-Padilla R, et al. Survival of patients with chronic obstructive pulmonary disease due to biomass smoke and tobacco. Am J Respir Crit Care Med. 2006;173:393-397.

125. González-García M, Maldonado Gomez D, Torres-Duque CA, et al. Tomographic and functional findings in severe COPD: comparison between the wood smoke-related and smoking-related disease. J Bras Pneumol. 2013;39:147-154.

126. Guarnieri MJ, Diaz JV, Basu C, et al. Effects of woodsmoke exposure on airway inflammation in rural Guatemalan women. PLoS One. 2014;9:e88455.

127. Rivera RM, Cosio MG, Ghezzo H, Salazar M, Pérez-Padilla R. Comparison of lung morphology in COPD secondary to cigarette and biomass smoke. Int J Tuberc Lung Dis. 2008;12:972-977. 
128. Aldrich MC, Munro HM, Mumma M, et al. Chronic obstructive pulmonary disease and subsequent overall and lung cancer mortality in low-income adults. PLoS One. 2015;10:e0121805.

129. Pleasants R, Herrick H, Liao W. Chronic obstructive lung disease in North Carolina: prevalence, characteristics and impact. $N \mathrm{C} \mathrm{Med} \mathrm{J.}$ 2013;74:376-383.

130. Dawkins P, Wood A, Nightingale P, Stockley R. Mortality in alpha-1antitrypsin deficiency in the United Kingdom. Respir Med. 2009;103: 1540-1547.

131. Sofianopoulou E, Rushton SP, Diggle PJ, Pless-Ulloli T. Association between respiratory prescribing, air pollution and deprivation, in primary health care. J Public Health. 2013;35:502-509.

132. Sutton W, Linn E. Where the Money Was: The Memoirs of a Bank Robber. New York: Viking Press; 1976:160.

133. Thakur N, Mcgarry ME, Oh SS, et al. The Lung Corps' approach to reducing health disparities in respiratory disease. Ann Am Thorac Soc. 2014;11:655-660.

134. Celedón JC, Roman J, Schraufnagel DE, Thomas A. Respiratory health equality in the United States. The American Thoracic Society Perspective. Ann Am Thorac Soc. 2014;11:473-479.

135. Celli B, Decramer M, Wedzicha JA, et al. An official American Thoracic Society/European Respiratory Society statement: research questions in COPD. Eur Respir J. 2015;45:879-905.

136. Respiratory diseases of the world: realities of today - opportunities for tomorrow. Available from: http:/www.thoracic.org/global-healthfirs-report-respiratory-diseases-in-the-world/index.php. Accessed January 20, 2016.

137. European COPD Coalition. Call to action on COPD. Available from: http://www.copdcoalition.eu/wp-content/uploads/2015/09/ECC-Callto-Action-010915-BD.pdf. Accessed January 28, 2016.

138. 19th World Health Organization Model List of Essential Medicines; April 2015.

139. World Health Organization framework convention on tobacco control; 2005

140. World Health Organization guidelines for indoor air quality: household fuel combustion; 2014.

141. World Health Organization. 2008-2013 action plan for the globa strategy for prevention and control of noncommunicable diseases.

142. World Health Organization. Prevention and control of non-communicable diseases: guidelines for primary health care in low-resource settings; 2012.

143. A global monitoring framework for noncommunicable diseases. Available from: http://www.who.int/nmh/events/2012/discussion_ paper3.pdf. Accessed January 23, 2016.

144. Beran D, Zar HJ, Perrin C. Burden of asthma and chronic obstructive pulmonary disease and access to essential medicines in low-income and middle-income countries. Lancet Respir Med. 2015;3:159-170.

145. Salvi S. The silent epidemic of COPD in Africa. Lancet Glob Health. 2015;3(1):e6-e7.

146. Ford ES, Croft J, Mannino DM, et al. COPD Surveillance - United States 1999-2011. Chest. 2013;144:284-305.

147. Pleasants R, Heidari K, Wheaton J, et al. Targeting chronic obstructive pulmonary disease by state-based surveillance. J Chron Obstruct Pulmon Dis. 2015;12:680-689.

148. Carré PC, Roche N, Neukirch F, et al. The effect of an information leaflet upon knowledge and awareness of COPD in potential sufferers. A randomized controlled study. Respiration. 2008;76:53-60.

149. Braido F, Baiardini I, Sumberesi M, Blasi F, Canonica GW. Obstructive lung diseases and inhaler treatment: results from a national public pragmatic survey. Respir Res. 2013;14:94.

150. Finn PW, Malhotra A. Health equality for pulmonary, critical care, and sleep medicine - opportunities for professional societies. Glob Heart. 2014;9:359-360.

151. A Nationwide Framework for Surveillance of Cardiovascular and Chronic Lung Diseases. Institute of Medicine (US) Committee on a National Surveillance System for Cardiovascular and Select Chronic Diseases. Washington (DC): National Academies Press (US); 2011.
152. Holt J, Huston SL, Heidari K, et al. Indicators for chronic disease surveillance - United States, 2013. Morb Mortal Wkly Rep. 2015; 64(RR01):1-15.

153. Hahn EJ, Rayens MK, Adkins S, et al. Fewer hospitalizations for chronic obstructive pulmonary disease in communities with smoke-free public policies. Am J Public Health. 2014;104:1059-1065.

154. Frazer K, Callinan JE, McHugh J, et al. Legislative smoking bans for reducing harms from secondhand smoke exposure, smoking prevalence and tobacco consumption. Cochrane Database Syst Rev. 2016;2:CD005992.pub3.

155. Physician behavior and practice patterns related to smoking cessation summary report. Association of American Medical Colleges. Available from: https://www.aamc.org/download/55438/data/. Accessed January 23, 2016.

156. Haas JS, Linder JA, Park ER, et al. Proactive tobacco cessation outreach to smokers of low socioeconomic status. a randomized clinical trial. JAMA Intern Med. 2015;175:218-226.

157. Neumann T, Rasmussen M, Ghith N, et al. The Gold Standard Programme: smoking cessation interventions for disadvantaged smokers are effective in a real-life setting. Tob Control. 2013; 22:e9.

158. Gordon SB, Bruce NG, Grigg J, et al. Respiratory risks from household air pollution in low and middle income countries. Lancet Respir Med. 2014;2:823-860.

159. United Nations Foundation Global Alliance for Clean Cookstoves and the Climate and Clean Air Coalition. Available from: http:/www. unfoundation.org/what-we-do/campaigns-and-initiatives/cookstoves/. Accessed January 23, 2016.

160. Smith KR, McCracken JP, Weber MW, et al. Effect of reduction in household air pollution on childhood pneumonia in Guatemala (RESPIRE): a randomised controlled trial. Lancet. 2011;378: 1717-1726.

161. Romieu I, Riojas-Rodríguez H, Marrón-Mares AT, Schilmann A, Perez-Padilla R, Masera O. Improved biomass stove intervention in rural Mexico: impact on the respiratory health of women. Am J Respir Crit Care Med. 2009;180:649-656.

162. Chapman BS, He X, Blair AE, Lan Q. Improvement in household stoves and risk of chronic obstructive pulmonary disease in Xuanwei, China: retrospective cohort study. Br Med J. 2005; 331:1050.

163. Alvis-Guzmán N, Alvis-Estrada L, Fernando de L. The cost of connecting poor households to natural gas in Colombia and its impact on health. Rev Salud Pública. 2014;14:1.

164. US Environmental Protection Agency. Standards of Performance for New Residential Wood Heaters, New Residential Hydronic Heaters and Forced-Air Furnaces. Available from: https://federalregister. gov/a/2015-03733. Accessed January 23, 2016.

165. Wang T, Niel W, Gao J, et al. Air quality during the 2008 Beijing Olympics: secondary pollutants and regional impact. Atmos Chem Phys. 2010;10:7603-7615.

166. Varkey JB, Varkey AB, Varkey B. Prophylactic vaccinations in chronic obstructive pulmonary disease: current status. Curr Opin Pulm Med. 2009;15:90-99.

167. Bonhoeffer J, Bär G, Riffelmann M, Solèr M, Heininger U. The role of Bordetella infections in patients with acute exacerbation of chronic bronchitis. Infection. 2005;33:13-17.

168. Damiani G, Federico B, Visca M, Agostini F, Ricciardi W. The impact of socioeconomic level on influenza vaccination among Italian adults and elderly: a cross-sectional study. Prev Med. 2007;45: 373-379.

169. Galarce EM, Minsky S, Viswanath K. Socioeconomic status, demographics, beliefs and A (H1N1) vaccine uptake in the United States. Vaccine. 2011;29:5284-5289.

170. de Lataillade C, Auvergne S, Delannoy I. 2005 and 2006 seasonal influenza vaccination coverage rates in 10 countries in Africa, Asia Pacific, Europe, Latin America and the Middle East. J Public Health Policy. 2009;30:83-101. 
171. Report 4 of The National Chronic Obstructive Pulmonary Disease Audit 2008 Patient Survey. The Royal College of Physicians of London, British Thoracic Society and British Lung Foundation. December 2008. Available from: https://www.rcplondon.ac.uk/file/. Accessed January 23, 2016.

172. Department of Health [UK]. Chronic Obstructive Pulmonary Disease National Service Framework: Development of the national service framework for COPD; Last modified August 13, 2007. Available from: http://collection.europarchive.org/tna/20080107220102/dh.gov. uk/en/Policyandguidance/Healthandsocialcaretopics/DH_4138532. Accessed January 23, 2016.

173. Lisspers K, Johansson G, Jansson C, et al. Improvement in COPD management by access to asthma/COPD clinics in primary care: data from the observational PATHOS study. Respir Med. 2014;108:1345-1354.

174. Plymouth University. FRESH AIR international research programme: Collaborating internationally to address the problem of lung disease. Available from https:/www.plymouth.ac.uk/research/primarycare/ fresh-air. Accessed January 23, 2016.

175. Khan MA, Ahmed M, Anil S, Walley J. Strengthening the delivery of asthma and chronic obstructive pulmonary disease care at primary health-care facilities: study design of a cluster randomized controlled trial in Pakistan. Glob Health Action. 2015;8:28225.

176. Goldstein RS, O'Hoski S. Telemedicine in COPD: time to pause. Chest. 2014;145:945-949.

177. Price D, Tinkelman DG, Nordyke RJ, Isonaka S, Halberty RJ. Scoring system and clinical application of COPD diagnostic questionnaires. Chest. 2006;129:1531-1539.

178. Martinez FJ, Raczek AE, Seifer FD, et al. Development and initial validation of a self-scored COPD Population Screener Questionnaire (COPD-PS). Chron Obstruct Pulmon Dis. 2008;5:85-95.

179. Hanania NA, Mannino DM, Yawn BP, et al. Predicting risk of airflow obstruction in primary care: validation of the lung function questionnaire (LFQ). Respir Med. 2010;104:1160-1170.

180. Calverley PM, Nordyke RJ, Halbert RJ, Isonaka S, Nonikov D. Development of a population-based screening questionnaire for COPD. Chron Obstruct Pulmon Dis. 2005;2:225-232.

181. Zhou YM, Chen SY, Tian J, et al. Development and validation of a chronic obstructive pulmonary disease screening questionnaire in China. Int J Tuberc Lung Dis. 2013;17:1645-1651.

182. Buist AS, McBurnie MA, Vollmer WM, et al. International variation in the prevalence of COPD (the BOLD study): a population-based prevalence study. Lancet. 2007;370:741-750.

183. Haroon S, Jordan R, Takwoingi Y, Adab P. Diagnostic accuracy of screening tests for COPD: a systematic review and meta-analysis. Br Med J Open. 2015;5(10):e008133.

184. Dirven JAM, Tange HJ, Muris JWM, et al. Early detection of COPD in general practice: patient or practice managed. A randomized controlled trial of two strategies in different socioeconomic environments. Prim Care Res. 2013;22:331-337.
185. Salpeter SS, Ormiston T, Salpeter E, Poole P, Cates C. Cardioselective beta-blockers for chronic obstructive pulmonary disease (Cochrane Review). Cochrane Database Syst Rev. 2005;4:CD003566.

186. Lammers JW, van Herwaarden CL. Ventilatory effects of long-term treatment with pindolol and metoprolol in hypertensive patients with chronic obstructive lung disease. Br J Clin Pharmacol. 1985;20: 205-210.

187. Chopra I, Chopra A, Bias TK. Reviewing risks and benefits of low-dose computed tomography screening for lung cancer. Postgrad Med. 2016; 6:1-8.

188. Rall FM, Grigg-Damberger M. Roles of gender, age, race/ethnicity, and residential socioeconomics in obstructive sleep apnea syndromes. Curr Opin Pulm Med. 2012;18:568-573.

189. Marin JM, Soriano JB, Carrizo SJ, Boldava A, Celli B. Outcomes in patients with chronic obstructive pulmonary disease and obstructive sleep apnea: the overlap syndrome. Am J Respir Crit Care Med. 2010; 182:325-331.

190. Hill K, Mangovski-Alzamora S, Blouin M, et al. Disease-specific education in the primary care setting increases the knowledge of people with chronic obstructive pulmonary disease: a randomized controlled trial. Patient Educ Couns. 2010;81:14-18.

191. Bazargani YT, de Boer A, Leufkens H, Mantel-Teeuwisse AK. Essential medicines for COPD and asthma in low and middle income countries. Thorax. 2014;69:1149-1151.

192. Babar Z, Lessing C, Mace C, Bissell K. The availability, pricing, and affordability of three essential medicines in 52 low- and middle-income countries. Pharmacoeconomics. 2013;31:1063-1082.

193. Vestbo J, Anderson JA, Calverley PM, Celli B. Adherence to inhaled therapy, mortality and hospital admission in COPD. Thorax. 2009;64:939-943.

194. 19th WHO Model List of Essential Medicines (April 2015). World Health Organization. Available from: http://www.who.int/medicines/ publications/essentialmedicines/EML2015_8-May-15.pdf. Accessed January 26, 2016.

195. Osterberg L, Blaschke T. Adherence to medication. $N$ Engl J Med. 2005;353:487-497.

196. Beran D, Zar HJ, Perrin C, Menezes AM, Burney P. Burden of asthma and chronic obstructive pulmonary disease and access to essential medicines in low-income and middle-income countries. Lancet Respir Med. 2015;3:159-170.

197. GoodRx, Inc. [homepage]. Available at: http://www.goodrx.com/. Accessed February 1, 2016.
International Journal of COPD

\section{Publish your work in this journal}

The International Journal of COPD is an international, peer-reviewed journal of therapeutics and pharmacology focusing on concise rapid reporting of clinical studies and reviews in COPD. Special focus is given to the pathophysiological processes underlying the disease, intervention programs, patient focused education, and self management protocols.

\section{Dovepress}

This journal is indexed on PubMed Central, MedLine and CAS. The manuscript management system is completely online and includes a very quick and fair peer-review system, which is all easy to use. Visit http://www.dovepress.com/testimonials.php to read real quotes from published authors. 